\title{
The Egyptian Predynastic and State Formation
}

\author{
Alice Stevenson ${ }^{1}$
}

Published online: 1 March 2016

(C) The Author(s) 2016. This article is published with open access at Springerlink.com

\begin{abstract}
When the archaeology of Predynastic Egypt was last appraised in this journal, Savage (2001a, p. 101) expressed optimism that "a consensus appears to be developing that stresses the gradual development of complex society in Egypt." The picture today is less clear, with new data and alternative theoretical frameworks challenging received wisdom over the pace, direction, and nature of complex social change. Rather than an inexorable march to the beat of the neo-evolutionary drum, primary state formation in Egypt can be seen as a more syncopated phenomenon, characterized by periods of political experimentation and shifting social boundaries. Notably, field projects in Sudan and the Egyptian Delta together with new dating techniques have set older narratives of development into broader frames of reference. In contrast to syntheses that have sought to measure abstract thresholds of complexity, this review of the period between c. $4500 \mathrm{BC}$ and c. $3000 \mathrm{BC}$ transcends analytical categories by adopting a practice-based examination of multiple dimensions of social inequality and by considering how the early state may have become a lived reality in Egypt around the end of the fourth millennium BC.
\end{abstract}

Keywords State formation - Social complexity - Neo-evolutionary theory · Practice theory $\cdot$ Kingship · Predynastic Egypt

\section{Introduction}

Forty years ago, the sociologist Abrams (1988, p. 63) famously spoke of the difficulty of studying that most "spurious of sociological objects" - the modern state. Anthropologists and archaeologists seeking to understand the early state have

Alice Stevenson

alice.stevenson@ucl.ac.uk

1 Petrie Museum of Egyptian Archaeology, University College London, Malet Place,

London WC1E 6BT, UK 
the perhaps more taxing task not only of addressing its character but of bridging the temporal and cultural removes from the areas they research. Yet grappling with state origins may present fresher ground for modeling how this knotty problem was established in the first place. The nature of the knot, however, remains a stubborn interpretive obstacle. Abrams' answer was that scholars should abandon attempts to conceptualize "the state" as if it existed as a cohesive, autonomous object and instead examine the "state-system" of practices and the "state idea" as it is projected and perceived. Such a project underpins this review of Predynastic Egypt.

During the latter half of the fifth millennium BC, society in Egypt largely comprised seasonally mobile agropastoralist groups. By the beginning of the third millennium BC that society had transformed into what is often considered the world's first "territorial state" (Trigger 1995), headed by the institution of divine kingship. Narratives accounting for this exceptional development have generally continued to coalesce around neo-evolutionist state theory (Andelkovic 2004, p. 535, 2006, 2008; Campagno 2002; Kemp 2006; Köhler 2010; Marcus 2008), despite extensive critiques when applied to other societies (e.g., Campbell 2009; Chapman 2003; Lull and Micó 2011; Pauketat 2007; Robb 2008; Routledge 2014; Terrenato and Haggis 2011; Wengrow and Graeber 2015; Yoffee 2005). More nuanced neo-evolutionary approaches, such as "dual-processual" theories (Blanton et al. 1996), have seldom been explored in relation to the early Egyptian evidence, although shifts in the relative importance of "corporate" to "network" strategies may have some relevance for understanding aspects of change between the early and mid-fourth millennium BC. In the literature on Predynastic Egypt, the concept of "chiefdoms" remains a resilient feature, albeit one frequently rebranded as "proto-states," "proto-nomes," or "proto-kingdoms." In such accounts the state itself is measured by investigating interdependent subsystems, while political authority tends to be homogenized as a singular, dominating force. The result is that the Egyptian state tends to be abstracted as an object and people rendered epiphenomenal to evolving elite ideologies. Fundamentally, these approaches do not fully penetrate the question of how a premodern, pristine state became a lived and sustained reality for both authorities and subjects. How does widespread political authority become transcendent and vested in the figure of a king who has a divinely mandated right to rule across a vast landscape?

More recent attempts to conceptualize such alterations to past social and political worlds have, like Abrams (1988), sought to surpass typologically based debates. Instead, they have appealed to historically specific processes and networks of practice in which the state exists not as a uniform sovereign territory but as an entity that is continually realized and performed through a web of power strategies, activities, and resources (Campbell 2009; Fleisher and Wynne-Jones 2010; Routledge 2014; Schortman 2014; Smith 2011). Methodologically, it is not enough to empirically identify the sources, structure, and variations of the state-system in traits such craft specialization or trade relations. It additionally requires examination of how the state idea itself was instantiated through the interpellation of a range of activities occurring across specific landscapes, diverse peoples, contingent histories, and material things. This synthesis of recent literature on Predynastic Egypt is constructed with these discussions in mind. 


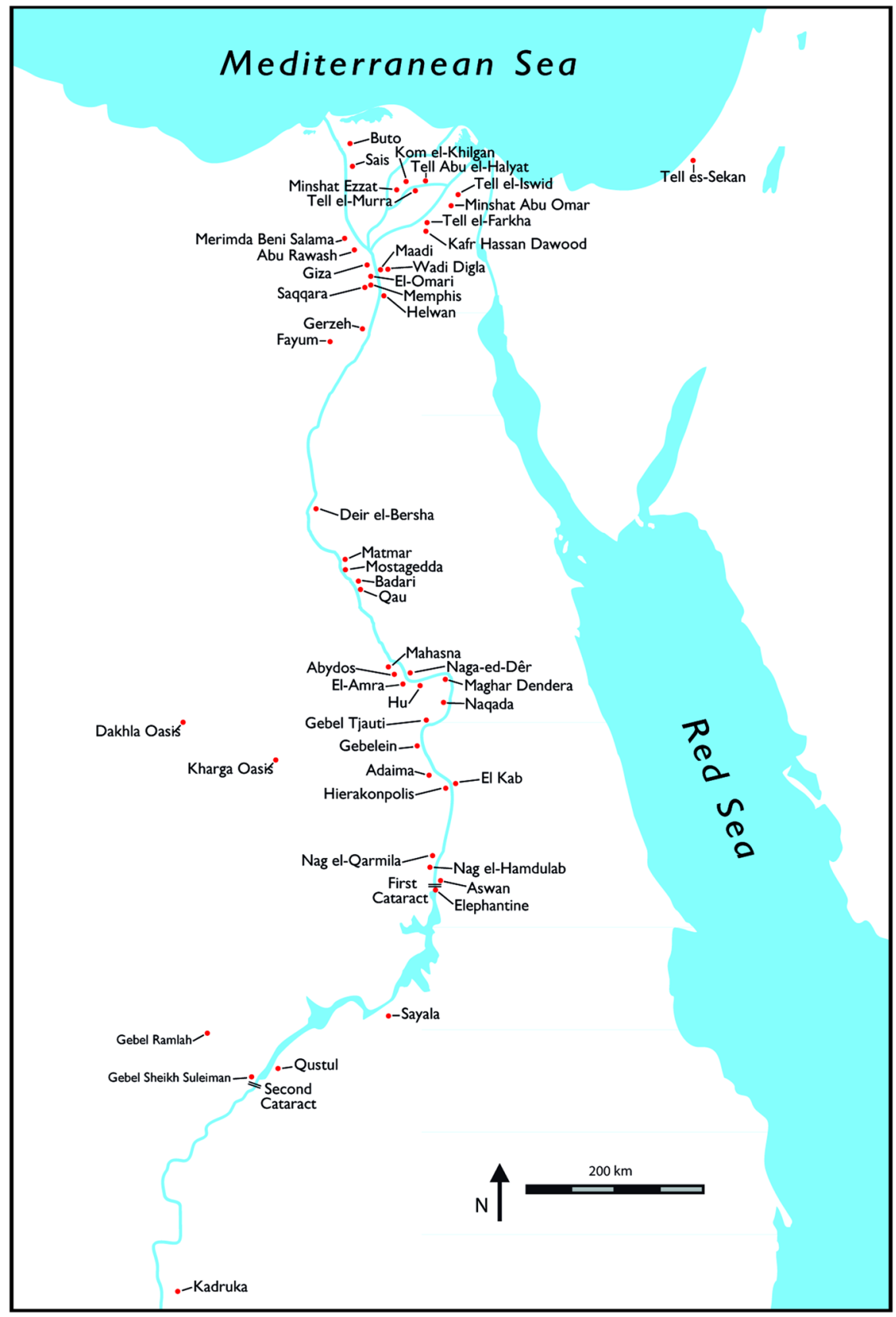

Fig. 1 Map of the sites mentioned in the text (drawn by Elli Petrocheilou) 
A second thread that informs this account is the development of new chronological models established through Bayesian analyses of radiocarbon estimates. By these means Egyptian state formation did not emerge along a gradual, linear trajectory of increasing inequality but instead can be seen as predicated on overlapping clusters of development, the location and nature of which ebbed and flowed across the centuries as the scale and, significantly, the orientation of social assemblages was negotiated. Within this flux five phases can be identified: (1) Neolithic/Badarian (c. 4400-3800 BC), the emergence of a new sense of place through agropastoralist activities; (2) Naqada IA-IIB (c. 3800/3750(?)-3450 BC), experimentation in the construction of local urbanizing communities and elite cosmologies; (3) Naqada IIC-D (c. 3450-3325 BC), expansion of social networks and the introduction of new sources of power; (4) Naqada IIIA-B (c. 3325-3085 $\mathrm{BC}$ ), processes of elite ascendancy, centralization, and the sedimentation of ideologies of kingship; and (5) Naqada IIIC/First Dynasty (c. 3085-2900 BC), dramatic shifts in the scale and nature of royal power. Each of these phases is characterized by alternative sets of strategies, different sources of and challenges to power, and varying social experiences.

\section{Temporal Threads}

Before setting out in more detail the ideas that inform this overview, I consider the establishment of Predynastic Egypt's temporal scale, not just because it has always been integral to the period's definition (Hendrickx 2006; Köhler 2011a; Spencer 2011) but because it has been central to its interpretation (Stevenson 2015a). Sequence dating of the Predynastic was famously established by Flinders Petrie (1899) through the application of gradualist, cultural-evolutionary frameworks to

Table 1 Approximate concordance of alternative relative dating systems and chronological terms for Predynastic Egypt (adapted from Hendrickx 2006, table II 1.1 and 1.3)

\begin{tabular}{|c|c|c|c|c|c|}
\hline $\begin{array}{l}\text { Petrie (1901a, 1920) } \\
\text { Brunton and Caton- } \\
\text { Thompson (1928) } \\
\text { cultures }\end{array}$ & $\begin{array}{l}\text { Petrie } \\
(1899) \\
\text { Sequence } \\
\text { dates }\end{array}$ & $\begin{array}{l}\text { Kaiser } \\
\text { (1957) } \\
\text { Stufen }\end{array}$ & $\begin{array}{l}\text { Hendrickx } \\
(1996, \\
1999) \\
\text { Naqada }\end{array}$ & Hassan (1988) & $\begin{array}{l}\text { Köhler } \\
\text { (2010) }\end{array}$ \\
\hline Badarian & $\mathrm{n} / \mathrm{a}$ & Badarian & Badarian & Early Predynastic & $\begin{array}{l}\text { Late } \\
\quad \text { Neolithic }\end{array}$ \\
\hline Amratian & $30-38$ & $\begin{array}{c}\text { Naqada } \\
\text { Ia-c }\end{array}$ & $\begin{array}{l}\text { Naqada I- } \\
\text { IIB }\end{array}$ & Middle Predynastic & Chalcolithic \\
\hline Gerzean & $38-62$ & $\begin{array}{c}\text { Naqada } \\
\text { IIa-d }\end{array}$ & $\begin{array}{l}\text { Naqada } \\
\text { IIC-D }\end{array}$ & Late Predynastic & $\begin{array}{l}\text { Late } \\
\text { Chalcolithic }\end{array}$ \\
\hline Semainean & $63-80$ & $\begin{array}{r}\text { Naqada } \\
\text { IIIa-c }\end{array}$ & $\begin{array}{l}\text { Naqada } \\
\text { IIIA-D }\end{array}$ & $\begin{array}{l}\text { Terminal Predynastic/ } \\
\text { Protodynastic/'Dynasty } \\
\text { 0' - Early Dynastic } \\
\text { Period/First Dynasty }\end{array}$ & $\begin{array}{l}\text { Early Bronze } \\
\text { Age }\end{array}$ \\
\hline
\end{tabular}


assemblages of funerary ceramics from the Upper Egyptian cemeteries of Naqada, Ballas, and Diospolis Parva (Hu/Hiw) (Fig. 1). Assumptions concerning the steady development of society remain implicit within this original scheme and subsequent chronologies. Consequently, gradualist thinking has continued to influence explanatory accounts of Predynastic development (e.g., Hoffman 1979, p. 117; Köhler 2010, p. 37; Midant-Reynes 2000, p. 255; Savage 2001a, p. 101).

Kaiser (1957) and Hendrickx (1996, 2006) reworked Petrie's innovative system into the "Naqada chronology," and it has continued to be scrutinized and refined, primarily in the development of localized site chronologies (Buchez 2011a; Hartmann 2011a, b; Hendrickx 2011a; Jucha and Mączyńska 2011; Stevenson 2009a, pp. 25-40). These efforts were undertaken with a view to establishing regional patterns of pottery production and consumption (Rowland 2009, 2013, p. 240). Few attempts, however, have been made to interleave this mosaic of increasingly detailed internal chronologies or to synthesize the processes behind the patterns. Temporal nomenclature for the period is consequently crowded with terms following a century of intensive study (Table 1). The most commonly used relative schema is that of Hendrickx (2006), and it is the one employed here.

The number of absolute dates for the Predynastic is still extremely limited in comparison to other areas of world archaeology. This is largely due to Egypt's antiquities laws, which forbid the export of any archaeological finds, however small, and the absence of accelerator mass spectrometry (AMS) facilities within the country. Only a handful of estimates have been obtained from recently excavated material (e.g., Friedman et al. 2011, p. 176; Midant-Reynes and Buchez 2002), but problems remain in sample selection (Dee et al. 2012), the ad hoc application of dates to archaeological features, and the lack of acknowledgment that multiple dates for single contexts are needed in order to construct chronological frameworks (Levine and Stanish 2014). Scepticism of the utility and veracity of radiometric techniques also persists (Hendrickx 2006; Köhler 2011a), despite improvements in the processing of samples (Dee et al. 2012) and the interpretation of radiometric estimates since the previous syntheses of Hassan (1985; Hassan and Robinson 1987) and Savage (2001b).

Most notable among these advances is the application of Bayesian statistical approaches, which have become standard practice for radiocarbon-based chronological analyses. This technique can enhance the precision of chronometric estimates (Bronk Ramsey 2009) and can make outputs more robust and reliable (Dee and Bronk Ramsey 2014; Lee and Bronk Ramsey 2012). Recent projects have employed these methods to critically assess early Egyptian chronology (Dee et al.

Table 2 Summary of absolute chronology (based on Dee et al. 2013)

\begin{tabular}{ll}
\hline Phase & Absolute estimate cal. BC \\
\hline Badarian & $4400-3800$ \\
Naqada IA-IIB & $3800 / 3750(?)-3450$ \\
Naqada IIC-D & $3450-3325$ \\
Naqada IIIA-IIIB & $3325-3085$ \\
Naqada IIIC-D/First Dynasty & $3085-2867$ \\
\hline
\end{tabular}


2013, 2014; Rowland 2009, 2013; Stevenson 2015a; Wengrow et al. 2014) and have greatly expanded the available data for early Egypt with the acquisition of more than 100 fresh measurements on organic materials from museum collections. The resulting Bayesian models have challenged previous generalizations that stretched Predynastic sociopolitical developments smoothly and evenly across the fourth millennium BC. Rather than the Predynastic being neatly bookended by millennial transitions, these models have confirmed the extension of fifth millennium cultural practices well into the fourth, while reducing Naqada I-III to around 700 years (Table 2). The timeline for the First Dynasty now has a generational-scale resolution, including a chronometric estimate for the accession of king Aha (c. 3080 $\mathrm{BC}$ ), who is often considered the founding ruler of the First Dynasty.

Like previous temporal frameworks, this revised timeframe retains the division of the Predynastic into discrete phases. Petrie's original partitioning of the archaeological evidence was predicated on the identification of invading cultures (the Amratian, Gerzean, and Semainean, named after cemeteries in Upper Egypt). These theories have long been abandoned as the indigenous character of Egyptian social change was recognized and as more nuanced understandings of Egypt's relationships with the outside world developed (Gatto 2014; van den Brink and Levy 2002; Wengrow 2006, 2010). Within this continuum, however, what warrants the demarcation of five distinct horizons is not only fundamental transformations in material culture but also distinctive shifts in social practices and geographies of power, developments that are more syncopated and complex than those presented in general accounts of state formation.

\section{Theoretical Threads}

Early 21st century studies of "archaic states" (Feinman and Marcus 1998) have witnessed a shift away from typological exercises focused on state origins toward more critical examinations of how polities operated (Stein 2001). In this vein, recent accounts of Predynastic state formation now recognize it as a longer-term multifaceted phenomenon, as opposed to a unification event as suggested in the earlier 20th century by Petrie and others. More recent reviews have instead explored the role of a variety of interleaving ideological, ecological, political, militaristic, and economic mechanisms in that process, rather than seeking any single ultimate cause (e.g., Anđelković 2004, 2006, 2008; Campagno 2002, 2011; Köhler 2010, 2011b). Nevertheless, implicitly underlying many approaches are neo-evolutionary assumptions. Other scholars have acknowledged more explicitly that neo-evolutionary schemas have their critics but remain adamant that frameworks rooted in the models first proposed by Service (1975) and Fried (1960) neatly fit the archaeological profile of early Egypt (e.g., Köhler 2010, p. 42). Kemp's (2006) “monopoly model," which posits that competition for prestige and power between rival chiefdoms at the centers of Hierakonpolis, Naqada, and Abydos in Upper Egypt initiated and drove social evolution, continues to be widely cited in this regard. The emergence of the state is assumed to have followed quickly on the heels of the consolidation of these polities into an "Upper Egyptian commonwealth" 
(Anđelković 2004) and its domination of Lower Egypt. The lack of reference to specific theoretical positions in Kemp's argument suggests deeply embedded suppositions, but the scenario he envisions is one familiar to anyone working on issues of complexity theory in other areas of the world, be that in Mississippi (e.g., Milner 1998) or Oceania (e.g., Cordy 1974). In these older accounts simple chiefdoms, with settlements organized around single centers, became integrated within one paramount center, thereby creating a complex chiefdom. The structure of the former was unaltered and the new, overarching polity remained an enlarged version of the qualitatively similar lower-order arrangement.

What these explanations often lack is a historicized sense of how, when, and in what specific contexts these transformations occurred. A second problem is that these models assume that the development of social inequality was an iterative, unitary phenomenon based solely on instrumental power of coercion and control. However, fresh thinking across anthropology and archaeology (e.g., Campbell 2009; Fleisher and Wynne-Jones 2010; Inomata and Coben 2006; Lohse 2007; Lohse and Gonlin 2007, p. xxiii; Routledge 2014), as well as in political geography and sociology (e.g., Desbiens et al. 2004, p. 242; Painter 2006), has presented state formation processes as more uneven, disjointed, and geographically variable than standard models because states exist through the active practices and relationships of a diversity of peoples, places, and institutions. Many of these studies, frequently drawing inspiration from the work of academics such as Mann (1986) and Bourdieu (1990), recognize that multiple sources of power are produced and articulated within particular social fields. Finally, neo-evolutionary models are problematic because they often belie the fragility and experimental nature of early political performances and formations (Anderson 1994; Wright 2006). There was always a chance they could fail, or at least falter, and current evidence for Predynastic Egypt suggests that they sometimes did.

Through the five phases of Predynastic development recognized in this paper, a clear dissonance in pathways to power can be charted when multiple dimensions of, and possibilities for, inequality are recognized. These inequities range from access to food resources and surpluses to exotic goods and sacred knowledge, dimensions that may overlap but not conjoin (Köhler 2010, p. 37). As Yoffee (2005, p. 22) has argued, it is not necessarily the case that social institutions, politics, economy, social organization, and belief systems were linked, or that they changed "at the same time, at the same pace, and in the same direction." That power can be structured through multiple fields of action was foregrounded by the introduction of the term "heterarchy" into archaeological usage (Crumley 1995). African-derived models of political power and authority have been particularly attentive to such alternative pathways to complexity (e.g., McIntosh 1999). These include the idea of "wealthin-people," for example, in which leaders are successful not simply because they gather and dominate others' labor but because they can marshal different sorts of knowledge (Guyer and Belinga 1995). Rather than instrumental power based on probabilities and capacities, leaders engage in creative acts of "composition," in which meaning is negotiated and invented (Fleisher and Wynne-Jones 2010; Schoenbrun 1999). 
The idea of the community has been similarly attractive in these contexts, both as a foil to impersonal perceptions of the state and in response to the growing interest in agency and practice (Harris 2014). Approaches to community have sought to move beyond views of the group as a natural given arising out of coresidency or copresence, to how it emerges through convivial and emotional engagements between people, things, and landscapes (DeMarrais 2011; Harris 2014; Whittle 2005). More critical understandings of what constitute communities recognize groups as continuously emergent through several crosscutting and nested scales (Harris 2014; Yaeger and Canuto 2000). Archaeologically, the contexts that have received the most attention for such models of community formation tend to be those centered on ritual. Vestiges of communal ceremonies are often the most visible aspects of the archaeological record, and ritual forms one of the key mechanisms of cultural change (Bell 1997; Rappaport 1999), including change toward social complexity (Aldenfelder 1993). State formation processes also can be examined through consideration of more prosaic practices that might give rise to "state effects" (Painter 2006). Wengrow (2006, p. 152), following Kus, for instance, acknowledges the value of examining both "bread and circuses" in transformations in Predynastic social complexity. It is an approach that entails being attentive to the material conditions of political action amid both elite and non-elite communities, and within both exceptional and quotidian circumstances.

I employ the above themes, either explicitly or implicitly, to review the archaeology of Predynastic Egypt and to take up Abrams' challenge to open up the very concept of the state.

\section{Neolithic Egypt}

For much of last century, the earliest evidence for the institutionalization of social inequality in Egypt was sought in Neolithic Egypt of the fifth millennium BC, when emmer wheat and six-row barley were introduced from Southeast Asia, some two millennia after domesticated cattle (Marshall and Hildebrand 2002). Such narratives had been constructed from only a handful of sites excavated in the early 20th century across three regions: the Badari area of Middle/Upper Egypt (Brunton and Caton-Thompson 1928), the Fayum (Caton-Thompson and Gardner 1934), and the Nile Delta (Debono and Mortensen 1990; Eiwanger 1982). Cereal cultivation did not, however, inevitably become the primary subsistence strategy, nor was it automatically accompanied by substantial year-round habitation. Commentators have noted the lack of evidence for permanent dwellings at several of these sites (e.g., Midant-Reynes 2000, p. 160; Wengrow 2006, pp. 63-64), while new investigations and closer scrutiny of older fieldwork have brought into relief the regionally variable character of the inception of Egypt's farming economies (Linseele et al. 2014).

In the Egyptian oases, studies have highlighted how the relationship between sedentism, food production strategies, and social complexity was not as straightforward as has often been assumed (see critique of earlier views in Feinman 1995, pp. 256-257). Prolonged periods of sedentism can be observed there before the fifth 
millennium BC, but this appears to have had no direct effect on the development of social complexity in the Egyptian Nile Valley (McDonald 2009, p. 37). These habitation zones are found principally during the early to mid-Holocene at the Dakhla and Kharga Oases, a period for which little trace of human activity in the Nile Valley has been recovered. With aridification, induced by the southward retreat of the monsoon belt around $5300 \mathrm{BC}$, these oasis groups reverted to more mobile pastoralist lifeways.

It is in the Western Delta of the fifth millennium BC that the most convincing signs of fully sedentary village life occur. In the later phases of Merimda Beni Salama (c. 4600-4100 BC), subterranean oval houses with mud foundations and internal hearths were excavated before the Second World War (Eiwanger 1982; Hassan 1985, pp. 104-105, 1988, pp. 150-151; Junker 1929). The Egypt Exploration Society's Imbaba Prehistoric Survey is currently reexamining the site, and initial surveys suggest that the Neolithic settlement (or settlements) covered a much wider area than had been supposed (Rowland 2015; Rowland and Tassie 2014). To the north, recent excavations at Sais (Sa el-Hagar) have demonstrated that habitation was focused principally on the sand hills (geziras) and levees of the Delta plain (Wilson 2006, 2014). There, however, the vestiges of structures are limited to pits and postholes. The majority of Delta "house burials," interred in what are probably the abandoned parts of settlements at el-Omari (Debono and Mortensen 1990, pp. 67-77) and Merimda, contain few or no offerings at all (e.g., Badawi 1978, p. 75; Junker 1929, pp. 185-202; Kemp 1968).

In contrast to the Merimda evidence, new archaeological data from around the Fayum's Lake Qarun have reemphasized that groups living there between 6500 and 6200 BP were more mobile than is usually expected for an agricultural society (Holdaway et al. 2010; Shirai 2010; Wendrich and Cappers 2005). The subsistence practices of such communities comprise a diverse mixture of hunting, gathering, and fishing activities, to which small-scale cereal production dependent on Mediterranean winter rains was added (Phillipps et al. 2012). Cultivation activities appear to have been concentrated not at the lake edge as once thought but at the seasonally watered wadi (valley) mouths.

While there seems to be broad agreement on the interpretation of the Lower Egyptian evidence, the socioeconomic basis of what is often considered the first Predynastic culture in the Nile Valley, the Badarian, is disputed. Sites were first uncovered at a series of cemetery and habitation locales along the desert margins of the Badari region, but they are now also represented farther south at Elkab (Claes et al. 2014), and, most substantially, at Maghar Dendera (Hendrickx et al. 2001). These communities are often characterized as the first village-based agriculturalists in Upper Egypt, despite the fact that the scale of cereal production seems to have been limited, while the occupation middens demonstrate rather ephemeral architecture more akin to temporary camping grounds than to settled villages (Wengrow 2006, pp. 63-64; Wengrow et al. 2014, p. 104). Nevertheless, several scholars maintain that Badarian groups were fully sedentary and that more substantial settlement debris may be buried deep beneath the ancient floodplain (Claes et al. 2014, p. 88; Hendrickx and Huyge 2014, pp. 246-247). 
What is more archaeologically definitive is the communal investment in formal cemetery areas, with individual graves conscientiously furnished with a range of material, most remarkably in eclectic personal ornamentation and complex treatments of the body (Wengrow et al. 2014), including resin-soaked textiles (Jones et al. 2014). In an otherwise rather sparse Neolithic archaeological record, the concentration of Badarian mortuary sites at Badari, Qau, Matmar, and Mostagedda had previously been considered exceptional, seemingly bursting onto the scene with an unexpected vibrancy, setting it apart from the evidence from the Sahara and Sudan (Midant-Reynes 2000, p. 152). However, the publication of several archaeological campaigns between the Fifth and Second Cataracts (e.g., Gatto 2011a, b; Sadig 2010; Salvatori and Usai 2008), from the Egyptian deserts (Friedman and Hobbs 2002; Kobusiewicz et al. 2004, 2009, 2010), and from the oases (Brios et al. 2012) — together with the new synthesis of associated radiocarbon dates from old excavations (Wengrow et al. 2014) - has made it possible to align the Badarian with the later phases of a broader Middle Holocene phenomenon that Wengrow $(2003,2006)$ has termed the "primary pastoral community."

The primary pastoral community is not envisioned to have been a discrete social unit, nor is it suggested that it represents a conscious identity shared by widely dispersed groups. Rather, it is a consistent set of concepts and practices focused on the body in life and in death that was shared by Nile Valley groups along a northsouth axis in the fifth millennium BC (Edwards 2004, pp. 49-59; Gatto 2011a; Wengrow et al. 2014). During this period, the landscape along the Nile Valley and the surrounding deserts accrued ancestral significance as seasonally mobile communities brought their dead, generation after generation, to be interred within small burial grounds, creating particular attachments to areas and routes of travel. In this manner communities emerged through "living people, the dead, things and places" (Fowler 2004, p. 95). The cemetery at Gebel Ramlah, for instance, encompassing 32 graves in Egypt's southwestern desert, contained a wealth of materials-some 568 discrete gifts-spread among 69 attentively furnished interments (Kobusiewicz et al. 2009, 2010). After lithic implements, the most common grave goods were items of personal adornment, including abundant beads, bracelets, lip plugs, shells, and colored pigments from a wide array of geographical sources. The pottery assemblage has direct affinities with contemporaneous Sudanese sites (Gatto 2010) at Kadruka (Reinold 2001) and R12 (Salvatori and Usai 2008). The model of the primary pastoralist community is useful, therefore, as a means of conceptualizing a ritual milieu in which cultural exchange across these areas was facilitated. The emphasis on its "pastoral" elements, however, remains to be fully qualified and can lead to an overly simplistic characterization of the socioeconomic foundation of Nile Valley societies. The Sudanese evidence is variable, suggestive of a diversity of strategies that in addition to pastoralist features included cultivation, hunting, and fishing.

It is within this wider framework-one that connects the Egyptian evidence to southern Nubian and Sudanese spheres-that the ill-defined Tasian culture is perhaps also better understood. It was first identified as a predecessor to the Badarian on the basis of about 50 burials in Middle Egypt, with such features as distinctive, richly decorated calciform beakers (Brunton 1937). More recently, the 
discovery of pottery beakers outside the Nile Valley similar to those from Tasian assemblages has led to proposals that Tasian groups should be considered as a desert-based society that interacted with Nile Valley Badarian communities (e.g., Briois et al. 2012, p. 188; Friedman and Hobbs 2002, p. 189; Gatto 2011b, p. 94). The Tasian pottery assemblage certainly demonstrates strong resemblances to the finds from Gebel Ramlah, including some affinities with calciform beakers (Gatto 2010). Nevertheless, the Tasian remains poorly represented archaeologically and its date relative to the Badarian is still unclear (Briois et al. 2012, p. 188; Ehrenfeld 2014; Gatto 2011b, p. 94; Hendrickx and Huyge 2014, p. 246).

Although the Badarian's connection to other fifth millennium BC Nile Valley communities has been brought into sharper focus by chronometric means, its relationship to the earliest Naqada groups in Upper Egypt continues to be opaque. Estimates now extend Badarian material culture into the earlier part of the fourth millennium BC (Dee et al. 2013; Wengrow et al. 2014), but no continuous transition to Naqada I-type assemblages has been found at any cemetery (Hendrickx 2006, p. 71). There are tentative suggestions based on cursory settlement excavations at Elkab that there was continuous occupation from Badarian stratigraphic levels through to Naqada I levels (Claes et al. 2014, p. 77), but there is no clear picture as to whether such habitation was of notable size, as is the case at Merimda. Chronologically, however, even when relative dating techniques are utilized, the temporal resolution of the roughly 600-year span of the Badarian remains coarse, in part because of the highly variable nature of the pottery (Math 2007). It has become increasingly clear that a unilinear model of development from Badarian to Naqadian culture cannot account for the evidence and that a more complex range of interactions between social groups underlies the similarities (Horn 2014, pp. 42-45).

Given the formulation of Badarian society as part of a longer-term, geographically expansive network and its coarse chronological resolution, earlier identifications of incipient wealth differentiation among burials as evidence for the emergence of a static, two-tiered or ranked society (e.g., Anderson 1992) seem simplistic. Agropastoralist groups implement a multitude of mobility patterns that permit fluidity in social formations over time and preclude the long-term stability of any one form of organization (Frachetti 2009, p. 25; Kelly 1992, pp. 49-45). Social differentiation and inequality was unquestionably part of this flux —as had probably been the case for millennia (Wengrow and Graeber 2015)_but they are not easily accommodated within a neat, linear neo-evolutionary framework that unequivocally tethers the evidence from Badarian contexts directly to institutionalized, permanent inequality of the character attested a millennium later.

\section{Naqada IA-IIB}

Whereas doubt may remain as to the socioeconomic structure of Badarian groups, it is clear that marked changes in community organization and social inequalities emerged only in the early fourth millennium BC (Naqada I), when more substantial proof for a sustained commitment to sedentary habitation and cereal agriculture is found. With these developments, the establishment of complex social formations in 
Naqada I was relatively swift and materially striking, most remarkably at the Upper Egyptian site of Hierakonpolis, as well as in the Delta toward the end of the phase.

Such evidence also now comes from a greater variety of sources. While Upper Egyptian mortuary sites continue to provide significant insights into Predynastic ritual life_-including work at Abydos cemetery U (Dreyer 1993; Dreyer et al. 1996, 1998, 2000, 2003, 2006, 2011), Adaïma (Crubézy et al. 2002), and Hierakonpolis cemeteries HK43 and HK6 (Friedman 2008b) —recent research agendas have begun to redress the dearth of habitation data (Tristant 2004) at Adaïma (Midant-Reynes and Buchez 2002), Mahasna (Anderson 2006), and el-Amra (Hill and Herbich 2011). These, however, are all relatively large, low desert sites, and data from the floodplain and from a wider variety of settlement sizes are still desperately needed (Anderson 2006, p. 265), although they may be extremely difficult to access. Nevertheless, with greater attention now being paid to geomorphological reconstruction of Nile River channel movements and their effects (e.g., Bunbury 2012), along with the success of archaeological exploration in the Delta, it should be a priority to model likely habitation locations for further study and to incorporate more detailed intersite spatial analyses. Delta locales are increasingly the focus for large-scale archaeological projects as more of the natural levees of the Nile branches that attracted human habitation are identified (Jucha and Mączyńska 2011; Tristant and De Dapper 2009; Tristant and Midant-Reynes 2011), including Tell elFarkha (Chłodnicki et al. 2012) and Tell el-Iswid (Midant-Reynes and Buchez 2014). There is a conspicuous absence of evidence for substantial prehistoric activity in the $300 \mathrm{~km}$ of Middle Egypt from north of the Badari region to the Fayum, although discoveries at Deir el-Bersha in Minya Province suggest that future investigations may begin to fill this lacuna (Bart 2014).

Naqada IA-IIB is characterized by marked regionality in material and visual culture both within Upper Egypt (Friedman 2000; Gatto 2011c) and between Upper and Lower Egypt, most starkly in the mortuary arena (Stevenson 2009b). In the southern Egyptian Nile Valley, groups retained a strong Nubian connection, as excavations in the Aswan area at Nag el-Qarmila, a settlement and cemetery site dating to Naqada IC-IIA, now demonstrate (Gatto 2011b, p. 94; Gatto et al. 2009). In the pottery and lithic assemblages are found both Nubian and Upper Egyptian style material, together with hybrid objects displaying traits associated with both areas. They additionally include a typical Upper Egyptian pottery bowl with a milled rim characteristic of Nubian decorative practices (Gatto 2014, p. 116). Such evidence challenges assumptions concerning sharp cultural boundaries between Upper Egyptian groups and Nubian "A-Groups" in the area of the First Cataract, pointing rather to an initial period of cultural entanglement and fluid interaction between communities, before more distinctive identities emerged in the course of the fourth millennium BC (Gatto 2014). In the Hierakonpolis region a unique complex of industrial, funerary, and ritual structures was established from around Naqada IC (see below). Farther north in the Abydos region, at Cemetery U, the earliest evidence for distinctive Upper Egyptian Naqada IA-B pottery assemblages is found (Hartmann 2011a, b). By Naqada IC the areas of Naqada and Abydos both shared broad categories of material culture with their southern neighbor, Hierakonpolis, but these were often deployed in novel ways and incorporated local 
stylistic traits, as is seen in Nile mud and clay objects (e.g., Hartung 2010), pottery fabrics and forms (Friedman 1994), and in the iconography of C-ware (e.g., Finkenstaedt 1980). Early Naqada I is poorly represented in the Badari region. In Lower Egypt, pottery traditions linked to what was initially designated the "MaadiButo" culture-now more generally referred to as "Lower Egyptian cultures"were substantially different from southern groups, and their mortuary display was far less ostentatious, with a high proportion of unfurnished tombs or tombs supplied with only a handful of ceramics. Lower Egyptian groups also exhibit diversity between settlement sites (Mạczyńska 2013). In these northern areas the scale, extent, and nature of relations with the Levant in the early Predynastic are subject to continued discussion (Hartung 2004; Mączyńska 2014a; van den Brink and Levy 2002; Wengrow 2006, pp. 83-89).

This patchwork of locally focused practices suggest that in the early Predynastic the orientation of social networks was more internally directed as communities sought to reconfigure relationships within the seasonality of cereal agriculture. Surveys of whole landscapes are largely lacking (but see Hoffman et al. 1986; Patch 1991, 2004), prohibiting wider contextualization within and between areas. Nevertheless, current excavations at sites such as Hierakonpolis and Tell el-Farkha permit exploration of how population coalescence and urbanization developed at the community level and how these new environments mediated in-group social relations.

\section{Upper Egypt}

Known in later ancient Egyptian times as Nekhen, Hierakonpolis-Greek "city of the falcon"- - has been subjected to intensive study in the last few decades, revealing the most complete picture of social complexity for the Naqada I-IIB period based on settlement, cemetery, ceremonial, and industrial spaces of activity (Friedman 2008a, 2011). It is the largest known site for the time, discontinuously stretching some $2.5 \mathrm{~km}$ along the desert edge and $3 \mathrm{~km}$ back into the Wadi Abu Suffian. Short seasons of exploration at the end of the 19th century first hinted at the unique character of the area (Quibell and Green 1902). Longer-term fieldwork in the 1970s and 1980s provided what is to this day the most fully documented account of "household" architecture for Predynastic Upper Egypt, in area HK29 (Hoffman 1980; Hoffman et al. 1986). More recent excavations at Hierakonpolis have yet to tackle these domestic contexts fully, although new excavations at HK11, $1.5 \mathrm{~km}$ within the Wadi Abu Suffian, has revealed what is described as a multiphase domestic structure in use between Naqada IC and IIC (Friedman et al. 2002b; Watrall 2001a, b). Nevertheless, these kinds of data are still limited, and Predynastic Egyptian archaeology is far from being able to engage the analytical scale of the "household" that has been described in many other parts of the world. In the absence of substantial intersite and intrasite comparative data, it is hard to assess just what sort of dwellings those uncovered might be, whether they are typical domestic spaces, or whether we are speaking of accommodation for attached specialists (e.g., Costin 2001). 
The picture that emerges from Hierakonpolis' shallow occupational debris is one of a lateral spread of ephemeral remains, as was found at Adaïma, a smaller settlement without specialized production units, reportedly composed of familybased dwellings (Bréand 2011, pp. 1016-1017; Buchez 2011b, pp. 33-34). Such patterns have been noted as a distinguishing feature between Egyptian urbanization and vertical tell-urbanization of Mesopotamian towns. Wengrow, for instance, suggests that given the transient nature of habitation remains in Upper Egypt more generally, early urbanization in Egypt occurred not amid spaces for the living but in the communities for the dead: "urbanisation of the dead may have been more important than the urbanisation of the living, the density of social memory more vital than the massing of permanent dwellings" (Wengrow 2006, p. 83).

Burial grounds, however, are not the only anchor to an increasingly urbanized life. Scholarship on urban landscapes tends to privilege the spread of the built environment and its architectural features, but as sociologist Molotch (2011) has argued, a phenomenon such as the city also can be understood as a "forest of artifacts" in which new densities of human relations are mediated by a density and a diversity of things. It is this increasing artifactual weight that shapes the social fabric of urban living. The debris may be shallow and the walls may be flimsy, but these early Egyptian sites exist to this day through the fragmentary mass of material lives. It is through artifactual residues that most of Predynastic Upper Egypt's habitation is currently known - at Naqada's South Town (Zawaydah), Adaïma, elMahasna, and el-Amra - and the discussions tend to take the form of analyses of small finds from amid the refuse of new ways of living (e.g., Anderson 2006, 2011; di Pietro 2011). Therefore, even though current investigations at Hierakonpolis concentrate on the industrial, ceremonial, and funerary localities of the site rather than habitation zones, these nonetheless demonstrate that vast quantities of diverse material and labor were mobilized around this place. Through the lived experience of things, in these places, new sorts of social memories would equally have been grounded and remade. They would have been present in the smoke rising from regularly or seasonally firing pottery kilns, the smells of the flourishing brewery industry, and the sounds of butchery, commerce, and ritual activities. All of these things are supported by current evidence.

Hierakonpolis' industrial quarter includes breweries for beer (HK24A), dating to around Naqada IIA-B, that are estimated to have been capable of producing 390 liters of beer by a single process (Geller 1992), as well as firing installations, possibly for pottery production (HK25D). These suggest highly integrated and organized modes of surplus production (Baba 2009; Takamiya 2008), dependent on staples (e.g., D’Altroy and Earle 1985). Labor-intensive, specialist production is further indicated by analysis of the emmer-wheat-rich residue from the insides of the vats at the slightly later (possibly from Naqada IIC) locality HK11C (operation A), an area deep within the wadi (Friedman 2009, p. 34), where some eight to ten installations have been located (Takamiya 2008). Further investigations suggest the presence of a second area (HK11C, operation B) for the processing of meat and fish, where large hearths and the sheer quantity of bones indicate that production was on a scale beyond domestic use (Baba 2014; Van Neer and Du Cupere 2014). The close proximity of HK11 to the elite burial ground, HK6 (see below), underscores how 
cult activities around the dead structured and engaged the activities of the living. Archaeobotanical examination of material from the non-elite cemetery HK43 correspondingly shows that cereals (including emmer wheat, hulled barley, freethreshing wheat and barley) were intensively cultivated around Hierakonpolis (Fahmy 2003, 2004).

Nearer the alluvium, a palisade wall enclosing an estimated 2.5 acres of land has been excavated (Hikade et al. 2008), in which workshops for the manufacture of large quantitates of beads, flint tools, and stone vessels were built. Around Naqada IIA-IIC a vast oval-shaped precinct (HK29A), $40 \mathrm{~m}$ by $13 \mathrm{~m}$ and delineated by wooden posts, was erected. Initial reconstructions mistook four large postholes at the south side as evidence for a monumental wooden shrine, linking it to later, dynastic architectural traditions (Friedman 1996; R. Wilkinson 2000, p. 17). Subsequent excavations have not verified such a structure, underscoring the dangers of imposing historic evidence onto prehistory. Instead, the postholes now seem to belong to a large acacia-wood courtyard entrance (Friedman 2009; Hikade 2011). Nevertheless, the special nature of the arena is still apparent from the profile of faunal remains, which indicate sacrificial butchery and feasting (Friedman 2009, p. 89; Linseele et al. 2009), an interpretation that is further bolstered by the distinctive nature of the fine-ware ceramic assemblage and lithic debris (Friedman 2009 , p. 83). A smaller-scale ritual arena also has been suggested to be present in the contemporaneous settlement at Mahasna, where a similarly varied concentration of zoological remnants and fine-ware ceramics, together with anthropomorphic and zoomorphic figurines, has been reported (Anderson 2011). The seasonal profile of the faunal vestiges in both locations, including wild desert and large aquatic species, has been linked to the inundation of the Nile (Anderson 2015; Perry 2011, pp. 1284-1285) and to the ideological emphasis on prowess in hunting (Hendrickx 2011b; Hendrickx and Eyckerman 2010, 2012). The general profile of these sites perhaps provides some insight into the character of festivals that seasonally attracted expectant crowds and, through feasting and spectacle, collectively wove together subsistence, economy, cosmology, and ritual experience. In these contexts, emerging leaders were not necessarily pursuing political ends but could creatively cast themselves as mediators associated with the regeneration of communities.

Around 14 cemetery localities have been recorded at Hierakonpolis (Friedman $2008 \mathrm{~b}$, table 1), and it is within these funerary contexts that the most celebrated discoveries have been made. For the period between IC and IIB a well-defined segregation of the burial population is apparent, with the most elaborate interments and associated architecture lying within deep within the wadi at HK6, while $2.4 \mathrm{~km}$ closer to the floodplain are necropolises like HK43, a cemetery of at least 453 comparatively modest burials constructed between Naqada IIA and IIC (the majority dated to Naqada IIB). Grave goods are uncommon across HK43, but even these more humbly furnished graves have revealed evidence of involved funerary practices focused on and around the body. Scalping, decapitation, manipulation of bones, and partial "mummification" (the application of resin-soaked linen to the heads and hands) have all been documented in HK43 (Dougherty and Friedman 2008), as well as at Adaïma (Crubézy and Midant-Reynes 2000; Crubézy et al. 2002, 2008). Secondary burial rites involving the rearrangement of disarticulated 
bones has long been a noted feature of the Predynastic (Wengrow 2006, pp. 114-120) and forms parts of a diversity of engagements and treatments of the body in death (Stevenson 2009b).

Palaeodemographic analysis of the HK43 sample suggests a population increase at that time, although previous estimates for 10,000 people are probably inflated (Batey 2012). Whatever the figure, it is far from being the "population explosion" described by some (e.g., Wenke 2009, p. 221), and population pressure leading to a competition for subsistence resources is an unlikely driver for social change in the Predynastic. Settlement surveys in the Abydos region have reached similar conclusions, observing low population numbers throughout the Predynastic (Patch 2004, p. 914). As Patch argues, the Abydos area has a wider floodplain than the more constricted Hierakonpolis section of the Nile. If there had been population pressure in the latter area, some evidence of expansion of communities would be expected to the north, but this has not been detected.

The elite cemetery HK6 has emerged as an especially dynamic landscape (overviews in Friedman 2008a, b, 2010). Almost 70 tombs, dating to Naqada IC-IIB and Naqada III, have so far been documented. The most sophisticated complex surrounds a large $4.3 \mathrm{~m}$ by $2.6 \mathrm{~m}$ tomb (number 16), dating to Naqada IC-IIA (Friedman et al. 2011). Material culture associated with it is unique, including two ceramic masks curved to fit over a human face. A wooden wattle-and-daub fence, seemingly decorated with a rich iconography, surrounded the tomb's surface, intersecting with other fences and enclosing subsidiary graves and grave groupings, forming the earliest evidence in Egypt for aboveground mortuary architecture. An inner ring of graves around tomb 16 was reserved for human burials, while an outer perimeter contained an eclectic range of carefully interred animal burials (Flores 2003; Friedman et al. 2011), including aurochs, baboons, an elephant, cats, and a hartebeest, along with 35 dogs. One or two generations later, in Naqada IIA-IIB, a second funerary complex was attended by an equally striking menagerie including a sheep, an ostrich, a leopard, a crocodile, aurochs, and baboons (Friedman 2012). A hippopotamus was found in association with tomb 12. This choreography of a variety of taxa around interments is unprecedented and underscores the centrality of an ideology based on control of the natural world. Among the human burials are some parallel phenomena, with two individuals from separate graves (47 and 51) exhibiting achondroplasia (dwarfism) (Pieri and Antoine 2012), a trait that conferred special status in later Egyptian times.

South of the tomb 16 complex is a series of columned halls and subterranean tombs of the slightly later IIA-B period, some aboveground burials of substantial size, while other columned superstructures stood apart. Tomb 23 is the largest known of the period and is associated with the deliberately shattered remains of Egypt's earliest known life-sized stone statue (Harrington 2004) and delicate animal figurines knapped in flint. Of the surrounding superstructures, the best preserved (number 07) measures $15 \mathrm{~m}$ by $10.5 \mathrm{~m}$ and is composed of 24 wooden columns with a variety of objects in the corners, from ostrich eggshells to elegantly knapped arrowheads and a carefully crafted malachite falcon. Most such luxury items were locally produced; evidence for imported material is scarce across Hierakonpolis at 
that time, suggesting that long-distance exchange was not yet a determining feature of sociopolitical life.

The excavators frequently refer to these finds as evidence for Egypt's earliest kings (Friedman 2008a, 2010), and Hierakonpolis is often reported as the originating source of Egyptian statehood (e.g., Marcus 2008, p. 260; Spencer 2011). These are without doubt high-status burials of a group of people whose social abilities enabled them to amass locally manufactured specialist goods, as well as to control surplus production that would have permitted them to sponsor feasts and ritual spectacle. Some elements of the iconography have echoes in later dynastic era visual representation, but the mechanisms by which these were incorporated centuries later are currently undertheorized, while the simple attribution of royal status and pharaonic ideology to prehistoric parallels runs the risk of anachronism (but see Baines 1995a, pp. 95-99). It should be noted that many of HK6's preNaqada IIC burials contain multiple human interments of both sexes and different ages (Friedman et al. 2011, p. 174), as is the case for cemetery T at Naqada (Petrie and Quibell 1896), which is often considered an area reserved for the elite. Attributing individual political roles there may be the wrong interpretive tact for these communal burials and claims for human sacrifices accompanying a primary individual have yet to be convincingly demonstrated (Dougherty 2010). More problematic is the implication that there was a straightforward, unbroken trajectory of social, political, and ideological development from Hierakonpolis to the establishment of the Egyptian state centuries later. Fundamentally, however, the formulation of elite burial ritual there bears limited relation to the forms adopted by Abydos-based rulers of Egypt at the close of the millennium. There is also a distinct break in the archaeological record at Hierakonpolis in Naqada IIC with the abandonment of cemeteries in the Wadi Abu Suffian, just one of many substantial changes witnessed across Egypt at that time (see below).

However impressive the remains at Hierakonpolis may be, they perhaps mask the possibility that aspiring leaders or ritual specialists based there lacked the means to extend control over surrounding regions because they were limited by an overreliance on the production and consumption of bulky, hard to transport "staple finance" goods (D'Altroy and Earle 1985, p. 188). Instead, the activities at Hierakonpolis might be better understood as a form of experiment (Wright 2006). Nevertheless, whether it be efficacious mortuary rituals in the cemetery or largescale feasting around the settlement, Hierakonpolis was a space for attracting a "density of social interaction" (Yoffee 2005, p. 62) that was in turn generative for new scales of collective action, affording the opportunity to regularize emergent sets of social relations and specialist social roles. But these sorts of intermittent, arguably seasonal, ritual events focused on control of the known natural world did not necessarily provide a basis for durable, expansive political structures.

\section{Lower Egypt}

Material culture distinctive from Upper Egyptian assemblages was first recognized in the region just south of modern Cairo around Maadi and Wadi Digla. Initially excavated between 1930 and 1953, the material was later found to be contemporary 
with the second half of Naqada I and early Naqada II (Rizkana and Seeher 1987, 1988, 1989, 1990). The traits noted there are now much better evidenced in the Nile Delta proper at the well-known site of Buto (von der Way 1992) and additionally in the northeastern Delta at Tell el-Farkha (Chłodnicki et al. 2012; Ciałowicz 2011) and Kom el-Khilgan (Buchez and Midant-Reynes 2007; Midant-Reynes et al. 2003, 2004; Tristant et al. 2008). Overall, some 24 sites have been attributed to Lower Egyptian cultures, all of a completely different character to those found at the earlier Neolithic sites of el-Omari and Merimda (Mączyńska 2013, table 1). The settlement sites are collectively characterized by light, poorly structured dwellings, while the cemetery areas of Kom el-Khilgan share with the Wadi Digla limited investment in mortuary provision in comparison to the display-oriented interments of Upper Egypt. Rescue excavations at Maadi have uncovered unique, stone-built semisubterranean houses (Hartung 2004). These have been interpreted as the work of itinerant foreigners based on similarities with Chalcolithic Beersheba structures in the southern Palestine, raising questions about the nature of relations with the Levant (Wengrow 2006, pp. 85-87).

Tell el-Farkha is the most expansive and best preserved of the Lower Egyptian sites. It is composed of three low hills or koms - the Western, Central, and Eastern Koms-across which numerous cemetery, settlement, and industrial installations have been unearthed, the earliest being a habitation locale established around Naqada IIB on the Western Kom (Adamski and Rosinska-Balik 2014, p. 23). The Western Kom was abandoned around the end of the fourth millennium BC, but the other two were occupied until the beginning of the Old Kingdom. This earliest area on the Western Kom includes a sequence of breweries, composed of a dozen large vats, indicating the possible establishment of localized systems of staple finance. The site has attracted considerable attention as a node along a trade route between the Levant and Upper Egypt (Mączyńska 2013, 2014a), one that became increasingly important in the subsequent Naqada IIC-D phase.

\section{Naqada IIC-D}

In contrast to the preceding period of in-group building, Naqada IIC-D can be characterized as a time of outward-looking strategies that encouraged greater fluidity in social interactions, evident in a broad series of changes in the archaeological record. These include fundamental transformations in ceramic production and technology, a wider distribution of material culture and practices first observed in Upper Egypt, a sharp increase in the circulation of exotic resources and the expansion of prestige-good systems, introduction of elite technologies such as sealing, shifts in settlement and cemetery patterns, and changes in visual culture and ritual media. Taken together, such transformations constituted new geographies of craft production, exchange, and consumption that mediated the scale and nature of community relationships.

Across a wide range of material culture, the shift toward the Naqada IIC-IID horizon is clearly discernable. In representational media, for instance, there was a reduction in the eclecticism that marked early Predynastic assemblages; artifacts 
like hand-modeled anthropomorphic figurines, decorated tusks, esoteric tags, unusually shaped maceheads, and zoomorphic models all disappeared, implying fundamental alterations in community ritual practices. It is in ceramic production and technology, however, that the most obvious changes are found (Hendrickx 2006, p. 78; Köhler 2014; Wengrow 2006, pp. 92-98). Local utilitarian pottery was by this phase completely substituted by what Petrie first termed "Rough-ware" (Rware), formed from a standardized, chaff-tempered fabric (Friedman 2000, p. 174). Its development has been linked to the centralized production of bread and beer, implying transformations in modes of dependency (Wengrow 2006, pp. 92-98). Other categories of pottery prevalent in the early Predynastic, such as Black-topped pottery (B-ware), dropped dramatically in number, while some forms disappeared completely, notably decorative white cross-lined pottery ( $\mathrm{C}$-ware). In their stead, new pottery classes were introduced that incorporated innovative technologies and materials of production like marl clay. These developments were not merely epiphenomenal, as these changing material conditions destabilized social relations and provided new opportunities for political action, social power, and ideological negotiation. The introduction of marl clay, for example, can be considered a "core material" for Naqada IIC-D (Boesch 1991, p. 332; Lemonnier 2012), linking multiple areas of social life and reproduction. It is thus worth looking at this material and its effects in some detail.

The fabric for marls is acquired not from Nile alluvial sources, as all previous Predynastic pottery had been, but has to be extracted via more complicated procedures from restricted desert locales. These vessels were probably created in new workshops that could fire this less malleable clay at higher temperatures, while the shapes fashioned in this medium were far more standardized and were likely mass-produced. Marl clay containers have been noted to be better suited for storage

Fig. 2 Example of a marl clay vessel, with both a wavy handle and red painted decoration typical of Naqada IIC-D (19.4 cm height), excavated at Gerzeh (tomb 101) (courtesy of the Petrie Museum of Egyptian Archaeology, UCL, UC10769)

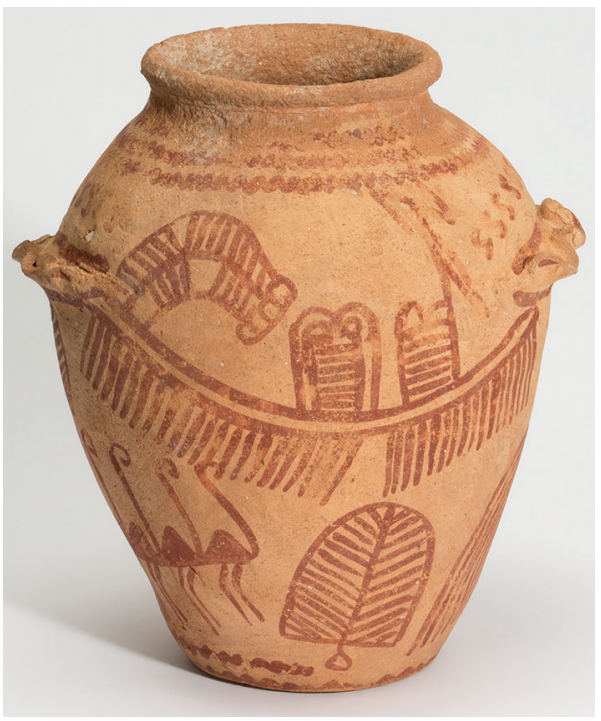


and transport than Nile silts (Buchez 2011a, p. 948). The decoration of marl clay containers is equally informative. Some containers incorporated ledge handles, Petrie's "Wavy-Handled" (W-ware), first seen on Levantine ceramics, connoting perhaps the luxury produce of wine and/or olive oil from that region (Czarnowicz 2012; Serpico and White 2000). Marl clay vessels were also the surface for a new and standardized visual culture, referred to as "Decorated ware" (D-ware) (Fig. 2), the red-painted iconography of which has continued to garner substantial attention and synthesis, albeit often quite speculative (Graff 2004, 2009). These designs repeated little of the hunting/militaristic themes or geometric patterns presented on C-ware of the previous phase (Hendrickx and Eyckerman 2010, 2012). Instead, it has been argued that they depict scenes associated with the afterlife (Graff 2003), a not unreasonable suggestion given that both $\mathrm{W}$-ware and $\mathrm{D}$-ware seem to be statistically better represented in burial rather than settlement contexts (Buchez 1998). Regardless of more specific readings, there seems to have been a shift away from the overt representation of domination to broader, more transcendent themes that may have better accommodated disparate groups, not insignificant given that Naqada IIC was also the time of the "Naqada expansion" (see below).

The calcareous clays necessary for the manufacture of marl fabrics have not been found in the Hierakonpolis region (Baba 2009, p. 4); the nearest sources are more than $50 \mathrm{~km}$ north at Esna, closer to the centers of Naqada and Abydos. If these marl clay vessels were intended for long-distance transport, referenced novel contents from abroad, played a role in ritual consumption, and were the medium for communicating a new iconography, control of their production may have been one factor that undermined persistent leadership strategies centered at Hierakonpolis by presenting new opportunities for social power that attracted and built broader, more diverse communities. Evidence for an iconography of militarism on the walls of the unique Naqada IIC Hierakonpolis painted tomb 100 has been argued to demonstrate continuity of the ideologies developed in the earlier Predynastic (Hendrickx and Eyckerman 2010). It is possible, however, that these images related to a strategy that was not deployed overtly or disseminated successfully northward beyond Hierakonpolis at the time. The abandonment of the elite cemetery HK6, the burning of wooden superstructures in the vicinity of grave 23, and the smashing of the life-sized human statue (Friedman 2008b, p. 22) suggest violent conflict or some form of iconoclasm in the region.

Whoever the instigators or promoters of these changes were, they succeeded in circulating their products widely. From Naqada IIC, Upper Egyptian material culture had a more extensive spatial distribution than had been the case in Naqada IIIB. Similar types of assemblages imported from Upper Egypt are found in considerable numbers southward to the Second Cataract of the Nile (Takamiya 2004). Northward, ten new cemetery sites with characteristic remains of Upper Egyptian material culture are known to have appeared in the Fayum, Memphite, and eastern Delta regions (Hendrickx and van den Brink 2002). Crucially, it was not simply the material culture that spread but additionally the practices associated with their use, including intricate mortuary displays and treatments of the body (Stevenson 2009b). 
The social processes by which these attributes and materials expanded from their Upper Egyptian source is contentious, with a spectrum of opinion existing on the relative importance of population movement, acculturation, and mutual interaction between the regions (Buchez and Midant-Reynes 2007; Ciałowicz 2008; Köhler 2008a, 2014; Mączyńska 2011, 2014b, pp. 193-200; Stevenson 2008, 2009a). Older models that proposed complete Upper Egyptian ascendancy over Lower Egyptian communities are no longer tenable in view of evidence from excavations in the Delta that demonstrate complex sequences of community affiliations (Ciałowicz 2008), as well as the contribution of Lower Egyptian technologies and practices to long-term developments, such as mud-brick architecture (Ciałowicz and DębowskaLudwin 2014). However, the continued dependence on typological analyses in the interpretation of intergroup dynamics in many of these debates elides wider contexts of the use and negotiation of material culture that might be revealing for the construction of social identities. Crucially, these will vary from site to site (e.g., Savage 1997; Stevenson 2008, 2009a), with interactions in the Fayum likely to be different from those in the more northern Delta sites, such as at Kom el-Khilgan (Buchez and Midant-Reynes 2011). However the "Naqada expansion" is interpreted, it demonstrates that communities were becoming increasingly linked across regional scales, which in turn implies a reconfiguration of status categories and political alliances. New research questions that address the social underpinnings of technological changes and open up the discussion to a greater range of theoretical possibilities, whether that be ethnogenesis, entanglement, or hybridity, are needed in order to tease apart these issues and to avoid reducing complex relationships to a dichotomy of acculturation versus migration.

Significantly, these expanding horizons crosscut broader currents of interactions that radiated throughout the Near East via the Uruk expansion (Wengrow 2006, pp. 135-137). The revision of temporal frameworks for fourth millennium BC Mesopotamia (Joffe 2000; Schwartz 2001; Wright and Rupley 2001) is meaningful in light of the more recent reassessment of Predynastic Egyptian chronology. In place of a short-lived phenomenon restricted to the Late Uruk period, an extension of Uruk material into Syria is recognized roughly around 3600-3400 BC (phase LC4). The new chronometric estimates from Egypt accommodate the evidence for Mesopotamian influences in Egypt far better than had previously been the case (Joffe 2000; Stevenson 2012). The spread of lapis lazuli from Afghanistan is a case in point. Lapis first appeared in Egypt sporadically in one or two graves during Naqada I/II, but it was not until Naqada IIC that its presence became marked across Upper Egyptian communities (Hendrickx and Bavay 2002, table 3.3). Similarly, imports of Near Eastern cylinder seals are first observed in Naqada IIC. Sealing practices, utilizing locally derived iconography, were then quickly adopted by IID, as evidenced at the elite cemetery U at Abydos (Hartung 1998, 2010; Hill 2004).

Limited numbers of Levantine ceramic imports are also present on Tell elFarkha's Western Kom (Czarnowicz 2012), where they are associated with a large, rectangular, mud-brick building around Naqada IID. The excavators of this structure refer to it as the "Naqadian residence," arguing that it was an administrative center constructed by settlers from political centers in Upper Egypt keen to control northern trade routes (Ciałowicz 2012). Certainly, significant numbers of donkey 
remains from the koms at Tell el-Farkha (Abłamowicz 2012) demonstrate the role of overland pack animals in facilitating intersocietal trade beyond the riverine transport systems of the Delta and Nile.

As settlement in the Delta became increasingly attractive for long-distance exchange, Upper Egyptian occupation patterns also shifted. From Naqada IID the settlement of Adaïma decreased in size, and sectors of the associated cemeteries were gradually abandoned (Buchez 2011b). Reexamination of data from the Armant region reveals similar phenomena (Buchez 2011b). At Abydos, despite the complete excavation of 680 burials at cemetery $U$, there are no known burials from the midNaqada IIB to late IIC/IID, suggesting social disruption in the region (Hartmann 2011b, p. 934). Similarly, evidence for a Naqada IIC-D phase at HK6 in Hierakonpolis is lacking (Friedman 2008a, p. 1189), with several other modest cemetery areas possibly being established at that time (Friedman 2008b, p. 23). Survey in the Abydos region has demonstrated that prior to Naqada IIC-D settlements and cemeteries were fairly evenly spaced along the low desert edge, but that by Naqada IID only cemeteries were located in the low desert, indicating that habitation zones had shifted closer to the river (Patch 1991, 2004), as seems also to be the case at Hierakonpolis (Hoffman et al. 1986). Overall, the number of graves attributed to the Naqada IIC-D horizon is far larger than for the preceding periods (Buchez 2011a, pp. 948-950), yet new chronological models (Dee et al. 2013) suggest that this was a much shorter span of time than previous chronologies had permitted.

Taken together, this evidence paints Naqada IIC-D as a time of rapidly expanding connectivity between communities and coalescence of existing ones. New external social orientations may have threatened the autonomy of previous social groups, transforming community reproduction and encouraging the nucleation of settlement. Some of these changes could be characterized as constituting a shift toward more networked political strategies (Blanton et al. 1996). Nevertheless, different forms of social capital were still widely dispersed across society, as can be seen in the spread of diverse materials across cemeteries up and down the country. Thus, lapis lazuli is found in a cross section of burials at multiple sites (Hendrickx and Bavay 2002; Savage 1997), as are fine stone vessels produced in a great multitude of stones (Kopp 2007; Stevenson 2011, p. 69). Specialist craft goods such as ripple-flaked knives, while restricted in number, are represented in all regions and not necessarily in the wealthiest tombs (Midant-Reynes 1987). With the exception of poorly furnished burials, no two Predynastic graves are identical. There existed a structure of choice in how burials were furnished, so that the location of different categories of material culture relative to each other is not consistent, with "rich" burials constituted in a number of ways, some with large quantities of pottery but little else, others with modest amounts of ceramics yet well equipped with exotic artifacts (Stevenson 2009c). This has similarly been suggested to characterize the formation of assemblages at Naga-ed-Dêr (Savage 1997; although see Delrue 2001). Such variability suggests that those individuals or groups who could negotiate the acquisition of precious materials from the outside world and sacred knowledge, for instance, were not necessarily the same as those who accumulated large numbers other commodities like marl clay vessels or small quantities of specialist craft 
produce. The further implication is that social, ritual, and political sources of power were not yet coterminous, with society being more widely prosperous than it had been for centuries previously or would be for several more. Overall, such a pattern may be indicative of the development in Naqada IIC-D of more heterarchical forms of social organization (Hayden 2001, p. 249).

\section{Naqada IIIA-B/C}

While the IIC-D period saw an expansion of a range of resources and sociopolitical opportunities, during Naqada IIIA-B - the "proto-dynastic" period or, for Naqada IIIB, the so-called "Dynasty 0" (Hendrickx 2006, pp. 88-89)—a group in the Abydos region was able to engineer a confluence of power over the broad array of
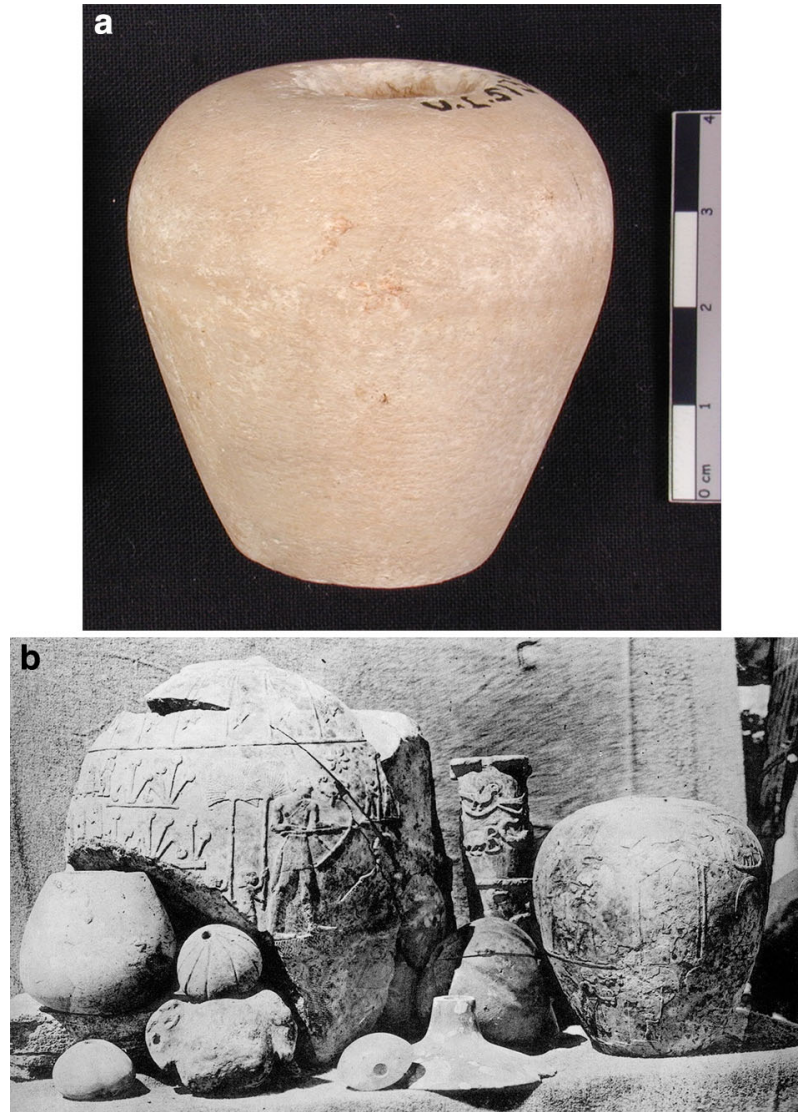

Fig. 3 a. Naqada IIC-D pear-shaped macehead (4 cm height) excavated at the eponymous site of Naqada (grave 1201) (courtesy of the Petrie Museum of Egyptian Archaeology, UCL, UC5132). b. 1898 photograph showing the ceremonial maceheads recovered from the 'Main Deposit' at Hierakonpolis (courtesy of the Petrie Museum of Egyptian Archaeology, UCL) 
potential resources. By the end of the phase they had extended their influence northward to the Levant. In other words, it is only in this period that wider-ranging creative acts of composition were able to be achieved vis-à-vis domination of external exchange networks, access to outside knowledge, accumulation of surplus staples, control of specialist craft production, and a monopoly over military might. These processes are easily obscured in scholarship that focuses solely on reconstructing political history, with many debates concentrating on the sequence of Dynasty 0 rulers and how to read their names-so-called king Scorpion or the mythical Menes-their affiliations, domains, and conquests (Anđelković 2011, pp. 30-31; Campagno 2013; Friedman et al. 2002a; Heagy 2014; Kahl 2006; T. Wilkinson 2000). Attempting to pinpoint which ruler(s) politically consolidated Egypt, however, may ultimately be archaeologically futile. Analyzing material processes and communal events through which state ideology was performed and made a lived reality for ancient communities, on the other hand, is a more relevant task of archaeology-in sociological terms recognizing structural effects of states (e.g., Mitchell 1991, p. 94).

One of the clearest documented processes is that of the appropriation or "entrainment" of community symbols toward ideologies of kingship (Routledge 2014, pp. 31-32). The elaboration of graywacke cosmetic palettes and pear-shaped maceheads (Fig. 3a) is a case in point. These object classes had been available for community reproduction and domestic ritual practices across Egypt for much of the Predynastic, but access to their raw materials, their production, and probably also the specialized contexts of their use was restricted in Naqada III by aspiring leaders who commissioned larger-scale, ceremonial versions, such as the Hierakonpolis maceheads (Fig. 3b) or the Narmer Palette, to materialize ideologies of kingship (Baines 2003, p. 36; Stevenson 2007; Wengrow 2001). Whereas themes of visual culture, such as those on decorated pottery, had previously been drawn from the known world, these ceremonial objects incorporated supernatural, composite images, such as serpopards and winged griffins, appropriated from Near Eastern glyptic representations (Wengrow 2013). Their fantastical nature lent them a unique position outside the indigenous repertoire of representation, forming appropriate references for the margins of the Egyptian's known world. They were thus easily accommodated within the developing elite's concern with "the containment of unrule" and the domination of order over chaos (Baines 1995b, pp. 13-14).

By these means long-standing cultural practices became more strongly allied with political authority. Simultaneously, the invention of novel technologies, such as writing, distanced these individuals yet further from broader society. These centralizing practices and the creation of "high culture" (Baines and Yoffee 1998) were accompanied by what Baines (2003) argues was an emptying out of symbolic capital for the majority of the population. This is seen across multiple domains of material culture from Naqada III into the First Dynasty (Stevenson 2011) in a process that has been termed the "evolution of simplicity" (Wengrow 2006, pp. 151-175; Yoffee 2001). Assertion of authority additionally involved a monopoly over the use of force and the threat of violence (real or ideological), although this is not overtly apparent in material assemblages (Gilbert 2004). It is, however, unambiguously portrayed in visual culture, not just on ceremonial palettes 
but also in rock art, such as a tableau depicting a king with a retinue of boats at Nag el-Hamdulab in Aswan (Hendrickx et al. 2012) and the Gebel Tjauti Rock inscriptions in the Western Desert that show bound captives and the sprawled bodies of defeated enemies (Friedman et al. 2002a).

These presentations leave all agency in the hands of one elite group. Emerging evidence from Tell el-Farkha, and from reexamination of early temple sites suggests, however, that toward the end of the fourth millennium BC there existed pockets of regional aesthetic diversity that ran parallel to these new narratives, indicated by localized forms of luxury goods and ritual practices (see also below).

\section{Upper Egypt}

Beneath the pottery-strewn desert surface of Abydos' Umm el-Qa'ab are the remains of what are arguably the first royal tombs in Egypt, framed by a dramatic backdrop of white limestone cliffs. The excavators' map of the cemeteries buried there (Fig. 4) reveals the contrast between the earlier Predynastic pit tombs and the Naqada III burials that lie beneath the southern part of cemetery U. These later tombs possess multiple chambers, outlined with mud-brick walls and roofed with wooden beams. Of these, by far the largest is the 12-chambered tomb U-j, dated to

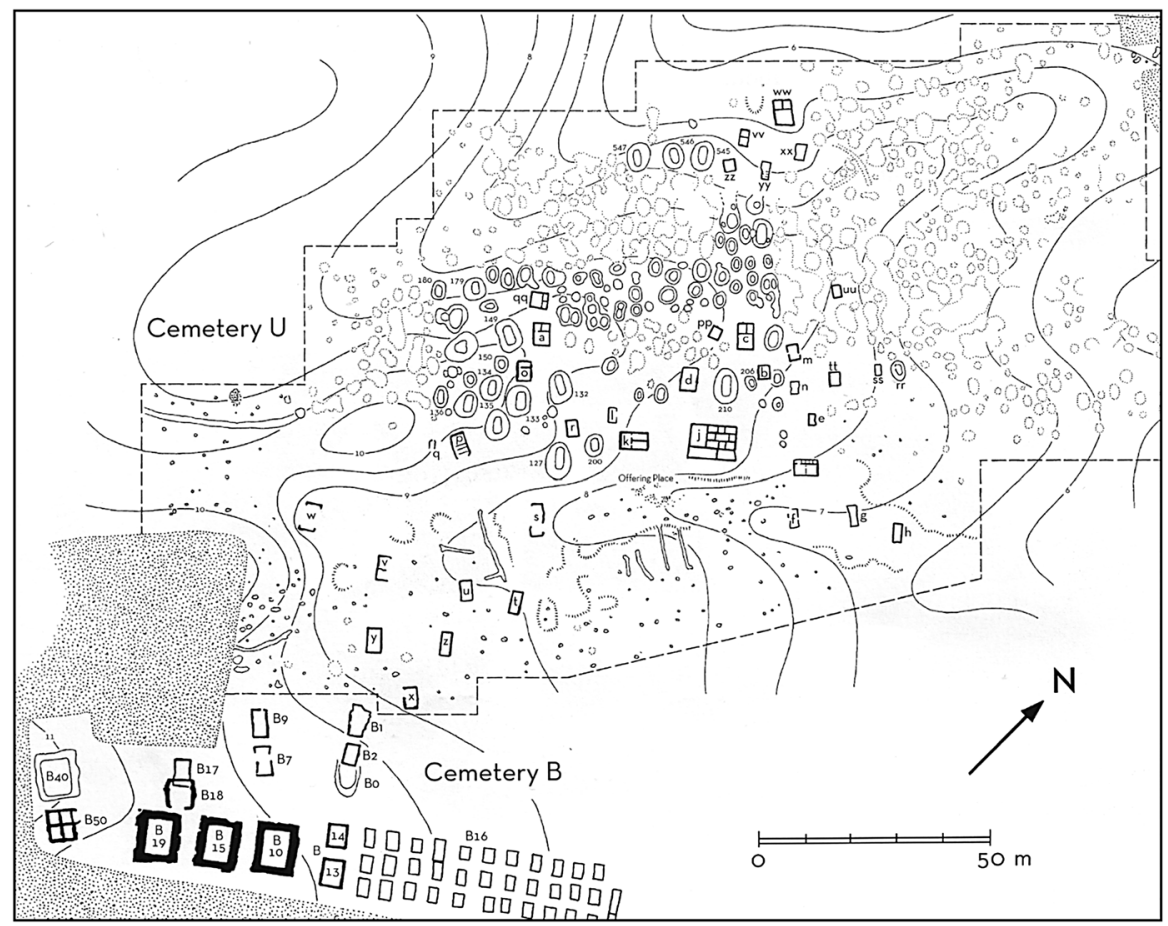

Fig. 4 Map of Cemeteries B and U, Umm el-Qa'ab, Abydos (courtesy of the DAI, Orient-Abteilung, Berlin). Cemetery U dates to the Predynastic; cemetery B is the location of the First and Second Dynasty royal tombs 
Naqada IIIA2 (Dreyer 1998, 2011), which despite plunder contained some 2000 clay vessels. More than a third of the ceramics were reported to be Palestinian imports (Hartung 2001), although one study indicated that these were largely local Egyptian imitations (Porat and Goren 2002). This latter interpretation, however, has been refuted by analysis of the pottery fabrics and also by examination of the imported contents, which have been revealed as fig, herbal, and tree-resin-infused wine (McGovern 2001; McGovern et al. 1997, 2001, 2009). This is the earliest confirmation of wine in Egypt, pointing toward new modes, scales, and visibilities of feasting, as well as novel modes of intoxication and social experiences. Other objects from tomb $\mathrm{U}-\mathrm{j}$, such as an expertly carved obsidian bowl and wooden chests made of cedar, additionally reveal substantial quantities of imported material.

Among this eclectic assemblage are the first known examples of hieroglyphic writing on small, square ivory tags (Baines 2010; Dreyer 1998; Kahl 2001). Assumptions that the establishment of a writing system equates with the introduction of elaborate administrative structures and bureaucratic control (e.g., Dreyer 1998, p. 89; T. Wilkinson 1999, pp. 41-44) have been robustly challenged (Baines 2004; Wengrow 2006, pp. 205-207, 2009, 2011). The evidence remains restricted to this exceptional tomb and to the burial ritual that framed it, leaving around two centuries between this and any equivalent examples.

In contrast to the material eclecticism of the Abydos interments, elsewhere in Egypt the material profile of graves became increasingly impoverished or "simplified" (Wengrow 2006, pp. 154-158), pointing toward an active restriction in materials, craft expertise, and possibly ritual specialists. For example, the variety of raw materials utilized for stone vessels was constricted except in elite contexts (Kopp 2007), the number, elaboration, and quality of cosmetic palettes declined (Stevenson 2007), and decorated pottery disappeared (Hendrickx 2006). The grave assemblages of the small Naqada III cemetery at Elkab typify this picture (Hendrickx 1994). At Hierakonpolis elite burials made a return to HK6 (Adams 2000), although in a much-diminished style compared to contemporary tombs at Abydos (Friedman 2008a, p. 23). Nevertheless, Naqada IIIA-B tombs there are relatively impressive, much more so than elsewhere in Upper Egypt. Their prosperity is possibly attributable to relationships with the Terminal Nubian A-Groups to the south. By this time, some members of Nubian society were able to participate in the exchange of an elite "international style" (Wengrow 2006, p. 171) that enabled new political formations in Nubian society to develop as expressed in sumptuous assemblages within the Nubian cemeteries of Qustul (Williams 1986) and Sayala (Firth 1927).

\section{Lower Egypt}

Although the most sacred Naqada IIIA-B mortuary ritual landscape centers around Abydos, the greatest concentration of Naqada III burials is in Lower Egypt, linked to a marked expansion of Nile Delta settlement (Dębowska-Ludwin 2013; Hendrickx and van den Brink 2002; Mawdsley 2012). Memphis was Egypt's preeminent urban center (Jeffreys and Tavares 1994), its significance being clear from the dramatic increase in sites and burials around it at the end of the 
Predynastic. The cemetery of Helwan is by far the largest necropolis, containing an estimated 10,000 or more tombs that date through to the Old Kingdom, but until recently it was poorly published (Saad 1969) and understood. Fieldwork directed by Köhler from 1997 to 2011 reexcavated select tombs to clarify chronology and tomb architecture and established that the cemetery was founded in Naqada IIIA (Köhler 2004, 2008b; Köhler and Birrell 2005; Köhler et al. 2014). In the Delta, numerous large sites have been identified, including Minshat Abu Omar (Kroeper 2004; Kroeper and Wildung 1994, 2000). Around 752 tombs have been reported at the much larger necropolis at Kafr Hassan Dawood. Only 233 have been chronologically assessed, but the main phases appear to be between Naqada IIIB and IIID (Hassan 2000; Rowland 2014).

One of the richest sources of data for Lower Egyptian developments comes from Tell el-Farkha, which had reached its apogee. For the first time, cemetery remains are present on the Eastern Kom along with settlement. The significance of the site is further indicated by the impressive scale of mud-brick architecture on the Western Kom. The most spectacular finds at Tell el-Farkha, however, were made in 2006 on the Eastern Kom, where two gold foil-covered figures (Fig. 5), which when reconstructed are $57 \mathrm{~cm}$ and $30 \mathrm{~cm}$ high, are thought to have been deposited in a poor settlement area around Naqada IIIB (Cialowicz 2012, p. 201). In the same season, a rich deposit of 62 carved figures (Fig. 6) - some in a previously unseen style-was recovered from a ceramic vessel on the Western Kom in association with the large mud-brick building interpreted as an "administrative-cultic" center established in Naqada IIIA (Ciałowicz 2007, 2011). The contents of this cache can be related to other enigmatic offerings recovered from what have been interpreted as

Fig. 5 Gold casing of a cult statue with lapis lazuli inlays around the eyes, from the Eastern Kom, Tell el-Farkha (courtesy of Krzysztof Ciałowciz and the Tell el-Farkha Expedition)

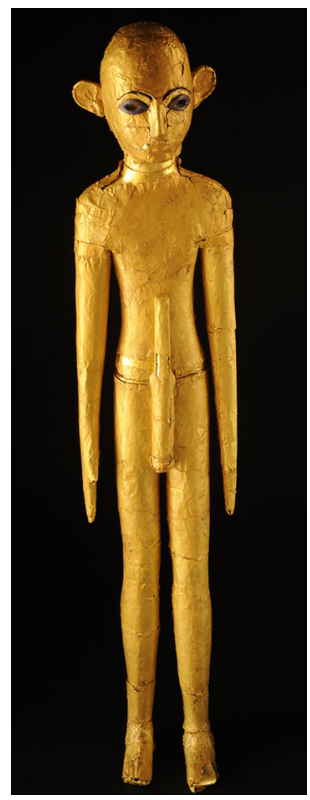




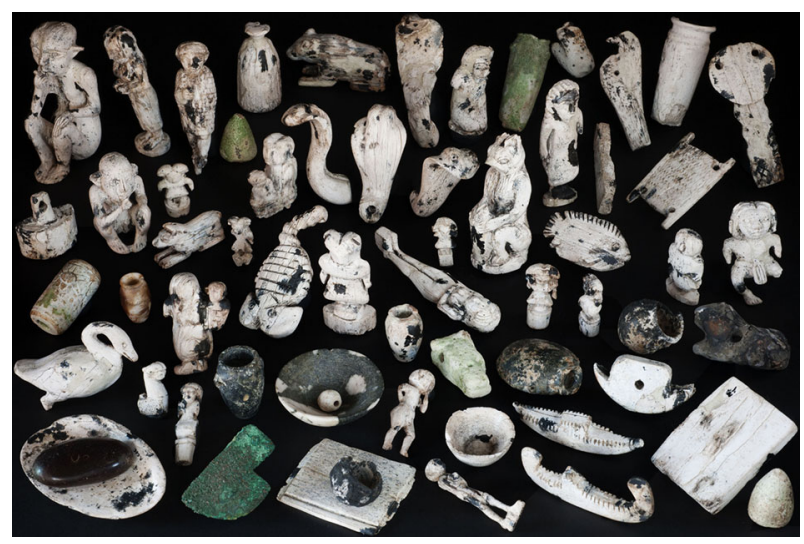

Fig. 6 Votive objects from a jar discovered on the Western Kom, Tell el-Farkha (courtesy of Krzysztof Ciałowciz and the Tell el-Farkha Expedition)

early temple deposits at Upper Egypt sites such as Elephantine, Hierakonpolis, and Abydos (summaries in Bussmann 2010, 2011; Kemp 2006). With the exception perhaps of material from Hierakonpolis (McNamara 2008), it has been argued that these artifacts were produced in local rather than centrally controlled workshops, betraying rather loose contact with the emerging court and the central ideology of kingship (Bussmann 2010, 2011).

The importance of the region around Tell el-Farkha has become even clearer with survey work led by the Polish Archaeological Survey in the Ash-Sharqiyyah Governate, where new settlement and cemetery sites like Tell el-Murra (Jucha 2010) and Tell Abu el-Halyat (Jucha 2011) have been identified. Overall, the northeastern Delta seems to have been quite densely populated at this time, with sites most likely located along the former Tanitic branch of the Nile (or subsidiaries) and the trading route leading from Egypt to northern Sinai and on to the Levant. The inhabitants of this pivotal region most likely profited from participation in trade, and it has been suggested that local elites in the region would consequently have had significant political and economic involvement in the events leading to the creation and consolidation of the Egyptian state (Jucha 2010, p. 386). Certainly there are several Naqada IIIB pottery vessels at Tell el-Farkha incised with examples of serekhs-rectangular devices that usually served as a frame for enclosing a ruler's name-which links the area to royal interests and property (Jucha 2012), although whether these were local rulers or rulers from the south is uncertain (T. Wilkinson 1999, pp. 52-58). Nonetheless, it is apparent that more complex forms of social organization developed in the Nile Delta at this time than had hitherto been considered.

\section{The Levant}

The evidence for intensive development in the northeastern Delta is complemented by a marked increase in the quantity of Egyptian-related material in the area of what 
is now the Gaza Strip and south-central Israel in Naqada IIIB (Braun 2004, 2011, 2014). Three, perhaps four, sites of the Early Bronze Age I in the southern Levant are claimed to have been populated by immigrants from Egypt. The most notable of these is the fortified site of Tell es-Sakan, founded on virgin soil, where the majority of material is Egyptian or Egyptianizing, including numerous royal names in serekhs of the Dynasty 0 rulers Ka and Narmer (de Miroschedji and Sadeq 2005). At other sites, lesser proportions of Egyptian artifacts are found relative to those in local traditions, raising questions about, and diverse opinions on, the relations between Egyptians and local communities, in addition to the nature of the Egyptian presence (Braun 2014, p. 49).

\section{First Dynasty}

In the final century of the fourth millennium $\mathrm{BC}$, during a particularly dry period (Bernhardt et al. 2012), there was a dramatic escalation in Egyptian royal funerary practices and depositions, beginning with the death of king Aha ("the fighter"), around $3080 \mathrm{BC}$ on the most recent dating (Dee et al. 2013). The monumental building programs and conspicuous ritual activity instigated by the rulers of the First Dynasty now demanded vast scales not only of labor but also of human life; hundreds of retainer burials were intimately constructed around the royal tombs (Engel 2008; Petrie 1900, 1901b). Such works were not just confined to the desert at Abydos' Umm el-Qa'ab. Also imposed on the landscape nearer the alluvium were massive, mud-brick walled enclosures likewise surrounded by subsidiary burials (Petrie 1925). In Lower Egypt at Saqqara, colorful, colossal-niched mortuary monuments (the largest extending over $50 \mathrm{~m}$ in length) called mastabas rose up on the plateau above the cliff along the skyline of the capital of Memphis, extravagantly filled with tens of thousands of offerings of pottery, stone, metals, and exotic materials (Emery 1961; Hendrickx 2008). At Abu Rawash and Giza smaller but nonetheless impressive funerary structures were built, with smaller numbers of retainer burials in close proximity (Tristant 2008a, b; Tristant and Smythe 2011). At the Early Dynastic town area of Hierakonpolis, a mud-brick gateway that dwarfed most mastaba tombs was built; although it has been referred to as forming part of a palace complex, in the absence of other evidence it is unclear to what sort of building it relates (Fairservis 1986).

The increased visibility of kingship across the Egyptian landscape was accompanied by a closure of the borders of the country (Baines 2003) and the construction of a mud-brick fortress at Elephantine (Siedlmayer 1996, p. 112). The Nubian frontier to the south was deserted by indigenous A-Groups, with rock art at places like Gebel Sheikh Suleiman in the Second Cataract suggesting a more aggressive attitude being taken by the Egyptian elite to their southern neighbors. At the same time, signs of Egyptian activity in the Levant completely disappeared and Tell es-Sakan was abandoned. As a result, the affluent communities in the northeastern Delta that had previously profited from trade relations in Naqada IIIAB experienced a slump, evident at Tell el-Farkha in the abandonment of the Western 
Kom, as well as at parts of nearby Tell el-Murra at the beginning of the Early Dynastic Period (Jucha 2010, p. 386).

A corollary of the increasing drama of elite life, however, was the long shadow that it cast over the majority of society who are, at present, largely absent from the material record and from archaeological narratives. This is due in part to the emptying out of symbolic capital for much of the population that had begun earlier in Naqada III and that by the mid-First Dynasty meant burials of the non-elite were frequently provided with a few poor-quality grave goods or none whatsoever. For instance, in the cemetery of the Eastern Kom at Tell el-Farkha, first established in Naqada IIIB, there was a marked reduction in the diversity and quality of grave goods from the mid-First Dynasty (Dębowska-Ludwin 2012). Many other sites have gone unreported or else have been difficult to date in the absence of associated material culture. It is therefore often hard to access the lived reality of Egypt under the First Dynasty rulers and to address more fully how political authority became vested in them. Temple sites in the provinces, nevertheless, convey some idea of local concerns that existed outside the state system and hint at a dissonance between centralizing efforts and provincial community activities.

\section{Royal Funerary Monuments}

The intensity of archaeological work in the Abydos region over the last century and a half has continued. First investigated by Amelineau in 1894-1898 and then by Petrie in 1900-1901, the royal cemetery B has been reexamined by teams from the Deutsches Archäologisches Institut (Dreyer 1993; Dreyer et al. 1996, 1998, 2000, 2003, 2006; Kaiser and Dreyer 1982). Although they are a continuation of cemetery $\mathrm{U}$, the burials of the First Dynasty rulers from the reign of king Aha onward in Cemetery B are of a very different character. Most obviously, they are orders of magnitude larger than their Dynasty 0 predecessors, with far more complex architectural features (Engel 2008). Djer's burial chamber was $10.4 \mathrm{~m}$ by $9.2 \mathrm{~m}$ in area, while the tomb of king Den was almost as large and sumptuously lined with pink granite brought from Aswan. These royal edifices additionally materialized a very different set of social relationships and economies of sacrifice than in Naqada IIIA-B (Stevenson 2015a; Wengrow 2006, p. 226). From the time of king Aha, rather than a single burial being set directly within the wider landscape of its forebears, each ruler's tomb lay within its own complex of carefully choreographed, well-furnished subsidiary burials especially created to accompany the ruler to the grave. In the case of king Djer, that included at least 318 individuals, and from his time onward each retainer burial was marked by rough limestone stelae bearing the names and administrative titles in crude hieroglyphs of the individuals entombed below (Martin 2011).

Similar retainer burials were located in the North Cemetery, more than $1 \mathrm{~km}$ from Abydos cemetery B, around contemporary royal cult mud-brick enclosures (O'Connor and Adams 2003; Petrie 1925). New excavations in the area have discovered three previously unknown precincts, all of them attributable to the reign of Aha (Bestock 2008, 2009; O'Connor 2009) and one belonging to an as yet unidentified ruler, although it is proposed on the pottery evidence to be that of king 
Narmer (Bestock 2012). The nature of the deaths of the roughly 2000 people interred around the First Dynasty royal monuments at Abydos, Saqqara, Abu Rawash, and Giza, is far from clear, although human sacrifice has become the commonly accepted cause (Baud and Étienne 2000; Morris 2007a, 2014). Certainly the demographic profile of the Aha retainer burials (all being young males in their 20 s), as well as the evidence that the ruler's burial and subsidiary tombs were roofed under one structure, supports this assertion. Regardless of whether sacrifice was the cause of death, it can be argued that the effectiveness of these royal funerary rites was enhanced by the way in which they focused emotional attention not just upon the spectacle of a ruler's burial but also on the loss of several hundred other individually named men and women. Therefore, the passing of a single specific person conceivably reverberated with emotional intensity in the lives of the hundreds of families whose mothers', fathers', brothers', sisters', sons', and daughters' deaths were all drawn toward that of the ruler. By exercising the visceral lived reality of the sovereign's power in these ways, kingship could be rendered ontologically different and transcendent (Stevenson 2015b).

Given that the titles of grave stelae suggest that the retainers around these elite monuments each held a specific official position (Martin 2011), their demise must have left conspicuous gaps in the social fabric of the court. This destruction of each ruler's court is mirrored in the decommissioning of the Abydos mortuary enclosures themselves, every one of which (with the exception of the last in the sequence, the second dynasty enclosure of Khasekhemwy) was systematically and ritually torn down before the next was erected (Bestock 2008, p. 49; O'Connor and Adams 2003, p. 84). Each precinct, therefore, rather than epitomizing continuous institutional rulership was related to one specific reign (Bestock 2008, p. 47). In this way the early Egyptian state was always in the process of being remade and performed in tangible, material ways. That it was reestablished despite the cost speaks volumes about the state's success in establishing symbolic continuity. This is most clearly materialized in the mud seals of the Umm el-Qa'ab necropolis, which list successive rulers whose cult was incorporated into that of their successors. As Abrams (1988, p. 76) noted, the idea of the state is a powerful reification, potentially concealing a disunity of political power and acting as a legitimation. It might therefore not so much be a question of when the Egyptian state emerged but rather at what point the balance between the state idea and state systems reached a tipping point, whereby the former became reified as a sacred entity, in the name of which order had to be continually restored. At the end of the fourth millennium BC, just such an extraordinary reification was irreversibly enacted.

\section{Provincial Communities and Practices}

State pageantry may have been highly visible in royal cemetery grounds, but it was intermittent. Finding evidence for the lower-order daily reification of state practices throughout Egypt is more difficult. There exists considerable uncertainty as to the scope of early third millennium BC royal administrative practices since they are confined to the central court (e.g., Engel 2013). Indirectly it may be inferred from the quantity, diversity, and quality of things that came to provision royal funerary 
structures and their cults, which would have required massive amounts of labor appropriated from across the country. It is most staggeringly apparent in the First Dynasty mastabas of Saqqara, such as number 3504 . At $49.5 \mathrm{~m}$ by $20 \mathrm{~m}$ in area, it is the largest structure of its time, with 68 internal storerooms containing around 2500 ceramic vessels (once full of thousands of liters of wine, beer, and other offerings), along with 1500 stone vessels in a wide array of materials (Emery 1954). Gold had been used extensively in the decoration of the burial chamber and the remains of other more perishable items of burial equipment were abundant even after extensive plundering. Outside of the tomb, a low bench wrapped around the exterior served as a platform for 300 pairs of real bull horns inserted into mud-shaped bucrania, while trenches around the mastaba's perimeter held the bodies of 62 men, women, and children. Altogether the amount of skilled craftsmanship, architectural sophistication, and ideological vigor that must have been commanded by the royal circle to achieve such monuments is impressive (Morris 2007b).

While the idea of the state that emerged in Naqada IIIA-B was intensified in the First Dynasty through this strong emphasis on royal funerary display, it nevertheless disguises the fact that state systems were still subject to ongoing development throughout, and long after, the First Dynasty. Following Scott's (1998) assertion that the premodern state did not penetrate society to the same degree as 20th-century states, Bussmann (2014) has argued for longer-term processes of state development in early Egypt. He notes that a mosaic of political geographies remains evident during the Old Kingdom (c. 2700-2150 BC), a polity of much larger scale than anything previous, but in which the organization of the political core did not align in any straightforward way with the arrangement of local community practices. The latter seems to have clustered around local shrines at provincial sites such as Elephantine (Bussmann 2010; Dreyer 1986) and Tell Ibrahim Awad (Eigner 2000), where there is a notable absence of any royal patronage or central administrative interest in the earliest stratigraphic levels of the buildings. These early mud-brick shrines were embedded within settlements and have revealed thousands of diverse, simply formed votive objects that speak to the concerns of ordinary people rather than the ideology of the state. As Bussmann notes (2015), it was not until central administration developed relationships with local temples centuries later that kingship became more meaningfully established in these areas in the long term.

\section{Conclusion}

The doctrine of sovereignty presents state power as being exercised uniformly across a bounded territory. If, however, analysis shifts away from modeling the state as a thing to conceptualizing it as an idea that is dynamically emergent through practices and relationships, somewhat different geographies and scales of power can be revealed. An approach of this sort, in contrast to neo-evolutionary canons, also has the advantage of leaving open the question of the character of early states, which is otherwise easily overlooked in favor of examining state origins.

In constructing new syntheses of Predynastic Egypt through practice-oriented narratives rather than rigid typological or political frameworks, archaeologists 
become better equipped to accommodate the fragmentary and complex data recovered from past lives. These attempts also reveal gaps. For Predynastic Egypt there remain fundamental lacunae in the data and opportunities to tackle new issues. Settlement data are sorely lacking, and broader regional surveys are needed to contextualize the few sites that have been subjected to intensive scrutiny. Full publication of excavations at Hierakonpolis and Tell el-Farkha, for example, will hopefully begin to provide the bases for such a renewed project, but these cannot be isolated interpretive projects. Wider-ranging, comparative explorations of the theoretical frameworks through which these sites are understood are also required. For instance, more sophisticated critical studies of social identities-as multiscalar, intersectional, and contingent phenomena-are lacking, and even basic questions about gender relationships remain to be tackled fully (cf., Hassan and Smith 2002).

Evidence from Predynastic Egypt also can speak to a much larger interpretive challenge. If Wengrow and Graeber (2015) are correct that for much of human history complex forms of hierarchy and political organization have always existed within a flux of construction and disaggregation, then tackling how and why intractable and permanent inequality was established at the end of the Predynastic takes on renewed relevance. To confront such a project means that a reappraisal of the very concept of the early Egyptian state and how we address it archaeologically is not only timely but necessary.

Acknowledgments I am enormously grateful to John Baines for his close reading of a first draft of this paper and for his insightful suggestions, and also to Xavier Droux for information about excavations at Hierakonpolis. Thanks are due to Gary Feinman for the invitation to write this piece and for his editorial guidance. Finally, I greatly appreciate the valuable feedback from the five peer reviewers who helped shape the final version.

Open Access This article is distributed under the terms of the Creative Commons Attribution 4.0 International License (http://creativecommons.org/licenses/by/4.0/), which permits unrestricted use, distribution, and reproduction in any medium, provided you give appropriate credit to the original author(s) and the source, provide a link to the Creative Commons license, and indicate if changes were made.

\section{References Cited}

Abłamowicz, R. (2012). Animal remains. In Chłodnicki, M., Ciałowicz, K. M., and Mączyńska, A. (eds.), Tell el-Farkha I: Excavations 1998-2011, Poznań Archaeological Museum, Poznań, pp. 425-430. Abrams, P. (1988). Notes on the difficulty of studying the state 1977. Journal of Historical Sociology 1: 58-89.

Adams, B. (2000). Excavations in the Locality 6 Cemetery at Hierakonpolis 1979-1985, Archaeopress, Oxford.

Adamski, B., and Rosińska-Balik, K. (2014). Brewing technology in early Egypt: Invention of Upper or Lower Egyptians? In Mączyńska, A. (ed.), The Nile Delta as a Centre of Cultural Interactions between Upper and Southern Levant in the 4th Millennium BC, Poznań Archaeological Museum, Poznań, pp. 23-36.

Aldenfelder, M. (1993). Ritual, hierarchy and change in foraging societies. Journal of Anthropological Archaeology 12: 1-40.

Anđelković, B. (2004). The Upper Egyptian commonwealth. In Hendrickx, S., Friedman, R. F., Ciałowicz, K. M., and Chłodnicki, M. (eds.), Egypt at Its Origins: Studies in Memory of Barbara Adams, Peeters, Leuven, pp. 535-546. 
Anđelković, B. (2006). Models of state formation in Predynastic Egypt. In Kroeper, K., Chłodnicki, M., and Kobusiewicz, M. (eds.), Archaeology of Early Northeastern Africa: In Memory of Lech Krzyżaniak, Poznań Archaeological Museum, Poznań, pp. 593-609.

Anđelković, B. (2008). Parameters of statehood in Predynastic Egypt. In Midant-Reynes, M., and Tristant, Y. (eds.), Egypt at Its Origins 2, Peeters, Leuven, pp. 1039-1056.

Anđelković, B. (2011). Political organization of the Egypt in the Predynastic period. In Teeter, E. (ed.), Egypt Before the Pyramids: The Origins of Egyptian Civilization, Oriental Institute, University of Chicago, Chicago, pp. 25-32.

Anderson, D. A. (2006). Power and Competition in the Upper Egyptian Predynastic: A View from the Predynastic Settlement at el-Mahâsna, Egypt, Ph.D. dissertation, Graduate Faculty of Arts and Sciences, University of Pittsburgh, Pittsburgh.

Anderson, D. A. (2011). Evidence for early ritual activity in the Predynastic settlement at el-Mahasna. In Friedman, R. F., and Fiske, P. N. (eds.), Egypt at Its Origins 3, Peeters, Leuven, pp. 3-30.

Anderson, D. A. (2015). A new look at old bones: Faunal remains from the Predynastic settlement at ElMahasna revisited. Paper presented at the 66th Annual Meeting of the American Research Center in Egypt, Houston, TX.

Anderson, D. G. (1994). The Savannah River Chiefdoms: Political Change in the Late Prehistoric Southeast, University of Alabama Press, Tuscaloosa.

Anderson, W. (1992). Badarian burials: Evidence for social inequality in Middle Egypt during the Early Predynastic era. Journal of the American Research Center in Egypt 29: 51-80.

Baba, M. (2009). Pottery production at Hierakonpolis during the Naqada II period: Toward a reconstruction of the firing technique. British Museum Studies in Ancient Egypt and Sudan 13: 1-23.

Baba, M. (2014). Meat and potatoes: A food factory at HK11C. Nekhen News 26: 20-21.

Badawi, F. A. (1978). Die Grabung der ägyptischen Altertümerverwaltung in Merimde-Benisalâme im Oktober/November 1976. Mitteilungen des Deutschen Archäologischen Instituts, Abteilung Kairo 34: $43-51$.

Baines, J. (1995a). Origins of Egyptian kingship. In O'Connor, D. B., and Silverman, D. P. (eds.), Ancient Egyptian Kingship: New Investigations, Brill, Leiden, pp. 95-156.

Baines, J. (1995b). Kingship, definition of culture, and legitimation. In O'Connor, D., and Silverman, D. P. (eds.), Ancient Egyptian Kingship: New Investigations, Brill, Leiden, pp. 3-47.

Baines, J. (2003). Early definitions of the Egyptian world and its surroundings. In Potts, T., Roaf, M., and Stein, D. (ed.), Culture Through Objects: Ancient Near Eastern Studies in Honour of P. R. S. Moorey, Griffith Institute, Oxford, pp. 27-57.

Baines, J. (2004). The earliest Egyptian writing: Development, context, purpose. In Houston, S. D. (ed.), The First Writing: Script Invention as History and Process, Cambridge University Press, Cambridge, pp. 150-189.

Baines, J. (2010). Aesthetic culture and the emergence of writing in Egypt during Naqada III. Archéo-Nil 20: $134-149$.

Baines, J., and Yoffee, N. (1998). Order, legitimacy and wealth in ancient Egypt and Mesopotamia. In Feinman, G., and Marcus, J. (eds.), Archaic States, School of American Research Press, Santa Fe, NM, pp. 199-260.

Bart, V. (2014). Rock circle cemeteries in the 15th and 16th Upper Egyptian nomes. In Midant-Reynes, B., and Tristant, Y. (eds.), Origins 5 Conference Abstracts, IFAO, Cairo, pp. 115-116.

Batey, E. K. (2012). Population Dynamics in Predynastic Upper Egypt: Paleodemography of Cemetery HK43 at Hierakonpolis, Ph.D. dissertation, Department of Anthropology, University of Arkansas, Fayetteville.

Baud, M., and Étienne, M. (2000). Le vanneau et le couteau: Un rituel monarchique sacrificiel dans l'Égypte de la Ire dynastie. Archéo-Nil 10: 55-77.

Bell, C. (1997). Ritual: Perspectives and Dimensions, Oxford University Press, Oxford.

Bernhardt, C. E., Horton, B. P., and Stanley, J.-D. (2012). Nile Delta vegetation response to Holocene climate variability. Geology 40: 615-618.

Bestock, L. (2008). The Early Dynastic funerary enclosures of Abydos. Archéo-Nil 18: 42-59.

Bestock, L. (2009). The Development of Royal Funerary Cult at Abydos: Two Funerary Enclosures from the Reign of King Aha, Harrassowitz, Wiesbaden.

Bestock, L. (2012). Brown University Abydos Project: Preliminary report of the first two seasons. Journal of the American Research Center in Egypt 48: 35-84.

Blanton, R. E., Feinman, G. M., Kowalewski, S. A., and Peregrine, P. N. (1996). A dual-processual theory for the evolution of Mesoamerican civilization. Current Anthropology 37: 1-14. 
Boesch, E. (1991). Symbolic Action Theory and Cultural Psychology, Springer, Berlin.

Bourdieu, P. (1990). The Logic of Practice, Stanford University Press Stanford, CA.

Braun, E. (2004). Egypt and the southern Levant: Shifting patterns of relationships during Dynasty 0. In Hendrickx, S., Friedman, R. F., Ciałowicz, K. M., and Chłodnicki, M. (eds.), Egypt at Its Origins: Studies in Memory of Barbara Adams, Peeters, Leuven, pp. 507-517.

Braun, E. (2011). Early interaction between peoples of the Nile Valley and the southern Levant. In Teeter, E. (ed.), Before the Pyramids: The Origins of Egyptian Civilization, Oriental Institute, University of Chicago, Chicago, pp. 109-126.

Braun, E. (2014). Reflections on the context of a late Dynasty 0 Egyptian colony in the southern Levant: Interpreting some evidence of Nilotic material culture at select sites in the southern Levant (ca. 3150-2950 BC). In Mączyńska, A. (ed.), The Nile Delta as a Centre of Cultural Interactions between Upper Egypt and the Southern Levant in the 4th Millennium BC, Poznań Archaeological Museum, Poznań, pp. 37-56.

Bréand, G. (2011). The corpus of pre-firing potmarks from Adaïma. In Friedman, R. F., and Fiske, P. N. (eds.), Egypt at Its Origins 3, Peeters, Leuven, pp. 1015-1041.

Briois F., Midant-Reynes B., Marchand S., Tristant Y., Wuttmann M., De Dapper M., LesurGebremariam J., and Newton, C. (2012). Neolithic occupation of an artesian spring: KS043 in the Kharga Oasis (Egypt). Journal of Field Archaeology 37: 178-191.

Bronk Ramsey, C. (2009). Bayesian analysis of radiocarbon dates. Radiocarbon 51: 337-360.

Brunton, G. (1937). Mostagedda and the Tasian Culture, British School of Archaeology in Egypt, London.

Brunton, G., and Caton-Thompson, G. (1928). The Badarian Civilisation and Prehistoric Remains near Badari, Bernard Quaritch, London.

Buchez, N. (1998). Le mobilier céramique et les offrandes à caractère alimentaire au sein des dépôts funéraires prédynastiques: Éléments de réflexion à partir de l'exemple d'Adaïma. Archéo-Nil 8: 85-103.

Buchez, N. (2011a). A reconsideration of Predynastic chronology: The contribution of Adaïma. In Friedman, R. F., and Fiske, P. N. (eds.), Egypt at Its Origins 3, Peeters, Leuven, pp. 939-951.

Buchez, N. (2011b). Adaïma (Upper Egypt): The stages of state development from the point of view of a 'village community.' In Friedman, R. F., and Fiske, P. N. (eds.), Egypt at Its Origins 3, Peeters, Leuven, pp. 31-40.

Buchez, N., and Midant-Reynes, B. (2007). Le site prédynastique de Kom el-Khilgan (Delta oriental): Données nouvelles sur les processus d'unification culturelle au IVe millénaire. Bulletin de l'Instiut Français d'Archéologie Orientale 107: 43-70.

Buchez, N., and Midant-Reynes, B. (2011). A tale of two funerary traditions: The Predynastic cemetery at Kom el-Khilgan. In Friedman, R. F., and Fiske, P. N. (eds.), Egypt at Its Origins 3, Peeters, Leuven, pp. 831-858.

Bunbury, J. M. (2012). The mobile Nile. Egyptian Archaeology 41: 15-17.

Bussmann, R. (2010). Die Provinztempel Ägyptens von der 0. bis zur 11. Dynastie. Archäologie und Geschichte einer gesellschaftlichen Institution zwischen Residenz und Provinz, Brill, Leiden.

Bussmann, R. (2011). Local traditions in early Egyptian temples. In Friedman, R. F., and Fiske, P. N. (eds.), Egypt at Its Origins 3, Peeters, Leuven, pp. 747-762.

Bussmann, R. (2014). Scaling the state: Egypt in the third millennium BC. Archaeology International 17: 79-93.

Bussmann, R. (2015). Egyptian archaeology and anthropology. Oxford Handbooks Online DOI:10.1093/ oxfordhb/9780199935413.013.24 (accessed 11/22/15).

Campagno, M. (2002). On the Predynastic 'proto-states' of Upper Egypt. Göttinger Miszellen 188: 49-60.

Campagno, M. (2011). Kinship, concentration of population, and the emergence of the state in the Nile Valley. In Friedman, R. F., and Fiske, P. N. (eds.), Egypt at Its Origins 3, Peeters, Leuven, pp. 1229-1242.

Campagno, M. (2013). Late fourth millennium BCE. In Grajetski, W., and Wendrich, W. (eds.), UCLA Encyclopedia of Egyptology, Department of Near Eastern Languages and Cultures, University of California, Los Angeles (https://escholarship.org/uc/item/9988b193).

Campbell, R. B. (2009). Toward a networks and boundaries approach to early complex polities: The Late Shang case. Current Anthropology 50: 821-848.

Caton-Thompson, G., and Gardner, E. W. (1934). The Desert Fayum, Royal Anthropological Institute, London. 
Chapman, R. (2003). Archaeologies of Complexity, Routledge, London.

Chłodnicki, M., Ciałowicz, K. M., and Mączyńska, A. (eds.) (2012). Tell el-Farkha I: Excavations 1998-2011, Poznań Archaeological Museum, Poznań.

Ciałowicz, K. M. (2007). Ivory and Gold: Beginnings of the Egyptian Art, Poznań Archaeological Museum, Poznań.

Ciałowicz, K. M. (2008). The nature of the relations between Lower and Upper Egypt in the Protodynastic period: A view from Tell el-Farkha. In Midant-Reynes, B., and Tristant, Y. (eds.), Egypt at Its Origins 2, Peeters, Leuven, pp. 501-514.

Ciałowicz, K. M. (2011). The Predynastic/Early Dynastic period at Tell el-Farkha. In Teeter, E. (ed.), Before the Pyramids: The Origins of Egyptian Civilization, Oriental Institute, University of Chicago, Chicago, pp. 55-64.

Ciałowicz, K. M. (2012). Protodynastic and Early Dynastic settlement on the Western Kom. In Chłodnicki, M., Ciałowicz, K. M., and Mączyńska, A. (eds.), Tell el-Farkha I: Excavations 1998-2011, Poznań Archaeological Museum, Poznań, pp. 163-180.

Ciałowicz, K. M., and Dębowska-Ludwin, J. (2014). Tell el-Farkha and its implications for understanding the earliest architecture of Lower Egypt. Studies in Ancient Art and Civilization 17: 25-40.

Claes, W., Hendrickx, S., Devillers, A., Hart, E., Kindermann, K., de Dapper, M., Ikram, S., Storms, G., Swerts, C., and Huyge, D. (2014). From the early Old Kingdom to the Badarian: Preliminary report on the 2012 excavation campaign in the settlement area of Elkab. In Mączyńska, A. (ed.), The Nile Delta as a Centre of Cultural Interactions Between Upper Egypt and the Southern Levant in the Fourth Millennium BC, Poznań Archaeological Museum, Poznań, pp. 73-94.

Cordy, R. H. (1974). Complex rank cultural systems in the Hawaiian Islands: Suggested explanations for their origins. Archaeology and Physical Anthropology in Oceania 10: 89-109.

Costin, C. L. (2001). Craft production systems. In Feinman, G. M., and Price, D. (eds.), Archaeology at the Millennium: A Sourcebook, Springer, New York, pp. 273-328.

Crubézy, E., and Midant-Reynes, B. (2000). Les sacrifices humains à l'époque prédynastique: L'apport de la nécropole d'Adaïma. Archéo-Nil 10: 21-40.

Crubézy, E., Janin, T., and Midant-Reynes, B. (2002). Adaïma 2: La nécropole prédynastique, Institut Francais d'Archeologie Orientale, Cairo.

Crubézy, E., Duchesne, S., and Midant-Reynes, B. (2008). The Predynastic cemetery at Adaima (Upper Egypt): General presentation and implications for the populations of Predynastic Egypt. In MidantReynes, B., and Tristant, Y. (eds.), Egypt at Its Origins 2, Peeters, Leuven, pp. 289-310.

Crumley, C. L. (1995). Heterarchy and the analysis of complex societies. In Ehrenreich, R. M., Crumley, C. L., and Levy, J. E. (eds.), Heterarchy and the Analysis of Complex Societies, American Anthropological Association, Washington, pp. 1-5.

Czarnowicz, M. (2012). Southern Levantine imports and imitations. In Chłodnicki, M., Ciałowicz, K. M., and Mączyńska, M. (eds.), Tell el-Farkha I: Excavations 1998-2011, Poznań Archaeological Museum, Poznań, pp. 245-266.

D'Altroy T., and Earle, T. (1985). Staple finance, wealth finance and storage in the Inka political economy. Current Anthropology 26: 187-206.

Debono, F., and Mortensen, B. (1990). El Omari, Philipp von Zabern, Mainz am Rhein.

Dębowska-Ludwin, J. (2012). Traces of early Egyptian burial rituals in Proto- and Early Dynastic graves from Tell el-Farkha. Studies in Ancient Art and Civilization 16: 39-48.

Dębowska-Ludwin, J. (2013). Early Burial Customs in Northern Egypt: Evidence from the Pre-, Proto-, and Early Dynastic Periods, BAR International Series 2571, British Archaeological Reports, Oxford.

Dee, M., Rowland, J. M., Higham, T. F., Shortland, A. J., Brock, F., Harris, S. A., and Bronk Ramsey, C. (2012). Synchronising radiocarbon dating and the Egyptian historical chronology by improved sample selection. Antiquity 86: $868-883$.

Dee, M., Wengrow, D., Shortland, A., Stevenson, A., Brock, F., Flink, L., and Bronk Ramsey, C. (2013). An absolute chronology for early Egypt using radiocarbon dating and Bayesian statistical modelling. Proceedings of the Royal Society A 469 DOI:10.1098/rspa.2013.0395 (accessed 09/14/15).

Dee, M. W., Wengrow, D., Shortland, A., Stevenson, A., Brock, F., and Bronk Ramsey, C. (2014). Radiocarbon dating and the Naqada relative chronology. Journal of Archaeological Science 46: 319-323.

Dee, M., and Bronk Ramsey, C. (2014). High-precision Bayesian modeling of samples susceptible to inbuilt age. Radiocarbon 56: 83-89. 
Delrue, P. (2001). The Predynastic cemetery N7000 at Naga ed-Dêr: A re-evaluation. In Willems, H. (ed.), Social Aspects of Funerary Culture in the Egyptian Old and Middle Kingdoms, Peeters, Leuven, pp. 21-66.

DeMarrais, E. (2011). Figuring the group. Cambridge Archaeological Journal 21: 165-186.

de Miroschedji, P., and Sadeq, M. (2005). The frontier in the Early Bronze Age: Preliminary soundings at Tell al-Sakan (Gaza Strip). In Clarke, J. (ed.), Archaeological Perspectives on the Transmission and Transformation of Culture in the Eastern Mediterranean, Oxbow Books, Oxford, pp. 155-169.

Desbiens, C., Mountz, A., and Walton-Roberts, M. (2004). Guest editorial: Introduction: Reconceptualizing the state from the margins of political geography. Political Geography 23: 241-243.

Di Pietro, G. (2011). Miscellaneous artefacts from Zaqaydah (Petrie's South Town, Naqada). In Friedman, R. F., and Fiske, P. N. (eds.), Egypt at Its Origins 3, Peeters, Leuven, pp. 59-80.

Dougherty, S. (2010). Death in fragments: Piecing together the skeletons of HK6. Nekhen News 22: 6-7.

Dougherty, S., and Friedman, R. F. (2008). Sacred or mundane: Scalping and decapitation at Predynastic Hierakonpolis. In Midant-Reynes, B., and Tristant, Y. (eds.), Egypt at Its Origins 2, Peeters, Leuven, pp. 311-338.

Dreyer, G. (1986). Elephantine VIII: der Tempel der Satet. Die Funde der Frühzeit und des Alten Reiches, Philipp von Zabern, Mainz am Rhein.

Dreyer, G. (1993). Umm el-Qaab: Nachuntersuchungen im frühzeitlichen Königsfriedhof, 5./6. Vorbericht. Mitteilungen des Deutschen Archäologischen Instituts Kairo 49: 23-62.

Dreyer, G. (1998). Umm el-Qaab 1: Das prädynastische Königsgrab U-j und seine frühen Schriftzeugnisse, Philipp von Zabern, Mainz am Rhein.

Dreyer, G. (2011). Tomb U-j: A royal burial of Dynasty 0 at Abydos. In Teeter, E. (ed.), Before the Pyramids: The Origins of Egyptian Civilization, Oriental Institute, University of Chicago, Chicago, pp. 127-136.

Dreyer, G., Blöbaum, A.I., Engel, E.-M., Köpp, H., and Müller, V. (2011). Umm el-Qaab: Nachuntersuchungen im frühzeitlichen Königsfriedhof, 19./20./21. Vorbericht. Mitteilungen des Deutschen Archäologischen Instituts Kairo 67: 53-92.

Dreyer, G., Effland, A., Effland, U. Engel, E.-M., Hartmann, R., Hartung, U., Lacher, C., Müller, V., and Pokorny, A. (2006). Umm el-Qaab: Nachuntersuchungen im frühzeitlichen Königsfriedhof, 16./17./ 18. Vorbericht. Mitteilungen des Deutschen Archäologischen Instituts Kairo 59: 67-138.

Dreyer, G., Engel, E.-M., Hartung, U., Hikade, T., Köhler, E. C., and Pumpenmeier, F. (1996). Umm elQaab: Nachuntersuchungen im frühzeitlichen Königsfriedhof, 7/8 Vorbericht. Mitteilungen des Deutschen Archäologischen Instituts Kairo 52: 11-81.

Dreyer, G., Hartmann, R., Hartung, U., Hikade, T. Kopp, H., Lacher, C., Müller, V., Nerlich, A., and Zink, A. (2003). Umm el-Qaab: Nachuntersuchungen im frühzeitlichen Königsfriedhof, 13/14/15 Vorbericht. Mitteilungen des Deutschen Archäologischen Instituts Kairo 62: 67-129.

Dreyer, G., Hartung, U., Hikade, T., Köhler, E. C., Müller, V., and Pumpenmeier, F. (1998). Umm elQaab: Nachuntersuchungen im frühzeitlichen Königsfriedhof, 9/10 Vorbericht. Mitteilungen des Deutschen Archäologischen Instituts Kairo 54: 77-167.

Dreyer, G., von den Driesch, A., Engel, E.-M., Hartmann, R., Hartung, U., Hikade, T., Müller, V., and Peters, J. (2000). Umm el-Qaab: Nachuntersuchungen im frühzeitlichen Königsfriedhof, 11/12 Vorbericht. Mitteilungen des Deutschen Archäologischen Institut, Kairo 56: 43-129.

Edwards, D. N. (2004). The Nubian Past: An Archaeology of the Sudan, Routledge, London.

Ehrenfeld, M. (2014). La phéomène tasien: Un état de la question. Archéo-Nil 24: 47-58.

Eigner, D. (2000). Tell Ibrahim Awad: Divine residence from Dynasty 0 until Dynasty 11. Ägypten und Levante 10: 17-36.

Eiwanger, J. (1982). Die neolithische Siedlung von Merimde-Benisalame. Mitteilungen des Deutschen Archaologischen Instituts, Abteilung Kairo 38: 67-82.

Emery, B. (1954). Great Tombs of the First Dynasty II, Egypt Exploration Society, London.

Emery, B. (1961). Archaic Egypt, Penguin, London.

Engel, E.-M. (2008). The royal tombs at Umm el-Qa'ab. Archéo-Nil 18: 30-41.

Engel, E.-M. (2013). The organisation of a nascent state: Egypt until the beginning of the 4th Dynasty. In Moreno García, J. C. (ed.), Ancient Egyptian Administration, Brill, Leiden, pp. 19-40.

Fahmy, A. G. (2003). Palaeothnobotanical studies of the Egyptian Predynastic cemeteries: New dimensions and contributions. In Neumann, K., Bulter, A., and Kahlheber, S. (eds.), Food, Fuel and Fields: Progress in African Archaeobotany, Heinrich-Barth-Institut, Cologne. 
Fahmy, A. G. (2004). Insights on the development of archaeobotanical and palaeothnobotanica: Studies in Egypt. In Hendrickx, S., Friedman, R. F., Ciałowicz, K. M., and Chłodnicki, M. (eds.), Egypt at Its Origins: Studies in Memory of Barbara Adams, Peeters, Leuven, pp. 711-730.

Fairservis, W. A. (1986). Excavation of the Archaic Remains East of the Niched Gate, Season of 1981: The Hierakonpolis Project, Vassar College, Poughkeepsie, NY.

Feinman, G. (1995). The emergence of inequality: A focus on strategies and process. In Price, D., and Feinman, G. (eds.), Foundations of Social Inequality, Plenum Press, New York, pp. 255-279.

Feinman, G. M., and Marcus, J. (eds.) (1998). Archaic States, School of American Research Press, Santa Fe, NM.

Finkenstaedt, E. (1980). Regional painting style in prehistoric Egypt. Zeitschrift für Ägyptische Sprache und Altertumskunde 107: 116-120.

Firth, C. M. (1927). The Archaeological Survey of Nubia: Report for 1910-1911, Government Press, Cairo.

Fleisher, J., and Wynne-Jones, S. (2010). Authorisation and the process of power: The view from Africa. Journal of World Prehistory 23: 177-193.

Flores, D. V. (2003). Funerary Sacrifice of Animals in the Egyptian Predynastic Period, BAR International Series 1153, Archaeopress, Oxford.

Fowler, C. (2004). In touch with the past? Monuments, bodies and the sacred in the Manx Neolithic and beyond. In Fowler, C., and Cummings, V. (eds.), The Neolithic of the Irish Sea: Materiality and Traditions of Practice, Oxbow, Oxford, pp. 91-102.

Frachetti, M. D. (2009). Differentiated landscape and non-uniform complexity Bronze Age societies of the Eurasian Steppe. In Hanks, B. K., and Linduff, K. M. (eds.), Social Complexity in Prehistoric Eurasia: Monuments, Metals and Mobility, Cambridge University Press, Cambridge, pp. 19-46.

Fried, M. H. (1960). On the evolution of social stratification and the state. In Diamond, S. (ed.), Culture in History: Essays in Honor of Paul Radin, Columbia University Press, New York, pp. 713-731.

Friedman, R. F. (1994). Predynastic Settlement Ceramics of Upper Egypt: A Comparative Study of the Ceramics of Hemamieh, Nagada, and Hierakonpolis, Ph.D. dissertation, Department of Near Eastern Studies, University of California, Berkeley.

Friedman, R. F. (1996). The ceremonial centre at Hierakonpolis locality HK29A. In Spencer, A. J. (ed.), Aspects of Early Egypt, British Museum Press, London, pp. 16-35.

Friedman, R. F. (2000). Regional diversity in the Predynastic pottery of Upper Egyptian settlements. In Krzyżaniak, L., Kroeper, K., and Kobusiewicz, M. (eds.), Recent Research into the Stone Age of Northeastern Africa, Poznań Archaeological Museum, Poznań, pp. 171-186.

Friedman, R. F. (2008a). Excavating Egypt's early kings: Recent discoveries in the elite cemetery at Hierakonpolis. In Midant-Reynes, B., and Tristant, Y. (eds.), Egypt at Its Origins 2, Peeters, Leuven, pp. 1157-1194.

Friedman, R. F. (2008b). The cemeteries of Hierakonpolis. Archéo-Nil 18: 8-29.

Friedman, R.F. (2009). Hierakonpolis Locality HK29A: The Predynastic ceremonial center revisited. Journal of the American Research Center in Egypt 45: 79-103.

Friedman, R. F. (2010). The early royal cemetery at Hierakonpolis: An overview. In Raffaele, F., Nuzzolo, M., and Incordino, I. (eds.), Recent Discoveries and Latest Researches in Egyptology, Harrassowitz, Wiesbaden, pp. 67-86.

Friedman, R. F. (2011). Hierakonpolis. In Teeter, E. (ed.), Before the Pyramids: The Origins of Egyptian Civilization, Oriental Institute, University of Chicago, Chicago, pp. 33-44.

Friedman, R. F. (2012). Lure of the leopard at HK6. Nekhen News 24: 4-6.

Friedman, R. F., Hendrickx, S., and Darnell, D. (2002a). Gebel Tjauti rock inscription 1. In Darnell, J. (ed.), Theban Desert Road Survey in the Egyptian Western Desert 1, Oriental Institute, University of Chicago, Chicago, pp. 10-17.

Friedman, R. F., and Hobbs, J. J. (2002). A 'Tasian' tomb in Egypt's Eastern Desert. In Friedman, R. F. (ed.), Egypt and Nubia: Gifts of the Desert, British Museum Press, London, pp. 178-191.

Friedman, R. F., Watrall, E., Jones, J., Fahmy, A.G., Van Neer, W., and Linseele, V. (2002b). Excavations at Hierakonpolis. Archéo-Nil 12: 55-68.

Friedman, R. F., Van Neer, W., and Linseele, V. (2011). The elite Predynastic cemetery at Hierakonpolis: 2009-10 update. In Friedman, R. F., and Fiske, P. N. (eds.), Egypt at Its Origins 3, Peeters, Leuven, pp. $157-191$.

Gatto, M. C. (2010). Pottery from Gebel Ramlah. In Kobusiewicz, M., Kabaciński, J., Schild, R., Irish, J. D., Gatto, M. C., and Wendorf, F. (eds.), Gebel Ramlah: Final Neolithic Cemeteries from the 
Western Desert of Egypt, Institute of Archaeology and Ethnology, Polish Academy of Sciences, Poznań, pp. 125-157.

Gatto, M. C. (2011a). The Nubian pastoral culture as link between Egypt and Africa: A view from the archaeological record. In Exell, K. (ed.), Egypt in Its African Context, BAR International Series 2204, Archaeopress, Oxford, pp. 21-29.

Gatto, M. C. (2011b). The relative chronology of Nubia. Archéo-Nil 21: 81-100.

Gatto, M. C. (2011c). Egypt and Nubia in the fifth-fourth millennia BC. In Friedman, R. F., and Fiske, P. N. (eds.), Egypt at Its Origins 3, Peeters, Leuven, pp. 859-877.

Gatto, M. C. (2014). Cultural entanglement at the dawn of the Egyptian history: A view from the Nile First Cataract region. Origini: Prehistory and Protohistory of Ancient Civilizations 36: 93-123.

Gatto, M. C., De Dapper, M., Gerisch, R., Hart, E., Hendrickx, S., Herbich, T., Joris, H., Nordström, H-A, Pitre, M., Roma, S., Swiech, D., and Usai, D. (2009). Predynastic settlement and cemeteries at Nag el-Qarmila, Kubbaniya. Archéo-Nil 19: 186-206.

Geller, J. R. (1992). From prehistory to history: Beer in Egypt. In Friedman, R. F., and Adams, B. (eds.), The Followers of Horus, Oxbow, Oxford, pp. 19-26.

Gilbert, G. P. (2004). Weapons, Warriors and Warfare in Early Egypt, BAR International Series 1208, Archaeopress, Oxford.

Graff, G. (2003). Les vases naqadiens comportant des representations d'addax. Cahiers Caribéens d'Egyptologie 5: 35-57.

Graff, G. (2004). Les peintures sur vases Nagada I-Nagada II: Nouvelle approche sémiologique. In Hendrickx, S., Friedman, R. F., Ciałowicz, K. M., and Chłodnicki, M. (eds.), Egypt at Its Origins: Studies in Memory of Barbara Adams, Peeters, Leuven, pp. 765-777.

Graff, G. (2009). Les peintures sur vases de Nagada I-Nagada II: Nouvelle approche sémiologique de l'iconographie prédynastique, Leuven University Press, Leuven.

Guyer, J. I., and Belinga, S. M. (1995). Wealth in people as wealth in knowledge: Accumulation and composition in Equatorial Africa. Journal of African History 36: 91-120.

Harrington, N. (2004). Human representation in the Predynastic period: The locality HK6 statue in context. In Hendrickx, S., Friedman, R. F., Ciałowicz, K. M., and Chłodnicki, M. (eds.), Egypt at Its Origins: Studies in Memory of Barbara Adams, Peeters, Leuven, pp. 25-44.

Harris, O. T. (2014). (Re)assembling communities. Journal of Archaeological Method and Theory 21: 76-97.

Hartmann, R. (2011a). Some remarks on the chronology of the early Naqada culture. Archéo-Nil 21: 21-32.

Hartmann, R. (2011b). The chronology of Naqada I tombs in the Predynastic cemetery U at Abydos. In Friedman, R. F., and Fiske, P. N. (eds.), Egypt at Its Origins 3, Peeters, Leuven, pp. 917-938.

Hartung, U. (1998). Prädynastische Siegelabrollungen aus dem Friedhof U in Abydos (Umm el-Qaab). Mitteilungen des Deutschen Archäologischen Instituts Abteilung Kairo 54: 187-227.

Hartung, U. (2001). Umm el-Qaab 2: Importkeramik aus dem Friedhof U in Abydos (Umm el-Qaab) und die Beziehungen Ägyptens zu Vorderasien im 4, Jahrtausend v.Chr, Phillip von Zabern, Mainz am Rhein.

Hartung, U. (2004). Rescue excavations in the Predynastic settlement of Maadi. In Hendrickx, S., Friedman, R. F., Ciałowicz, K. M., and Chłodnicki, M. (eds.), Egypt at Its Origins: Studies in Memory of Barbara Adams, Peeters, Leuven, pp. 337-356.

Hartung, U. (2010). Hippopotamus hunters and bureaucrats: Elite burials at cemetery U at Abydos. In Raffaele, F., Nuzzolo, M., and Incordino, I. (eds.), Recent Discoveries and Latest Researches in Egyptology, Harrassowitz, Wiesbaden, pp. 107-120.

Hassan, F. A. (1985). Radiocarbon chronology of Neolithic and Predynastic sites in Upper Egypt and the Delta. The African Archaeological Review 3: 95-116.

Hassan, F. A. (1988). The Predynastic of Egypt. Journal of World Prehistory 2: 135-186.

Hassan, F. A. (2000). Kafr Hassan Dawood. Egyptian Archaeology 16: 37-39.

Hassan, F. A., and Robinson, S. W. (1987). High-precision radiocarbon chronometry of ancient Egypt, and comparisons with Nubia, Palestine and Mesopotamia. Antiquity 61: 119-135.

Hassan, F. A., and Smith, S. (2002). Soul birds and heavenly cows. In Rosen-Ayalon, M. (ed.), In Pursuit of Gender, AltaMira Press, Oxford, pp. 43-65.

Hayden, B. (2001). Richman, poorman, beggarman, chief: The dynamics of social inequality. In Feinman, G. M., and Price, T. D. (eds.), Archaeology at the Millennium: A Sourcebook, Kluwer Academic/ Plenum Press, New York, pp. 213-272.

Heagy, T. C. (2014). Who was Menes? Archéo-Nil 24: 59-92. 
Hendrickx, S. (1994). Elkab V: The Naqada III Cemetery, Musées Royaux d'Art et d'Histoire, Brussels.

Hendrickx, S. (1996). The relative chronology of the Naqada culture: Problems and possibilities. In Spencer, A. J. (ed.), Aspects of Early Egypt, British Museum, London, pp. 36-69.

Hendrickx, S. (1999). La chronologie de la préhistoire tardive et des débuts de l'histoire de l'Egypte. Archéo-Nil 9: 13-81.

Hendrickx, S. (2006). Predynastic-Early Dynastic chronology. In Hornung, E., Krauss, R., and Warburton, D. A. (eds.), Ancient Egyptian Chronology, Brill, Leiden, pp. 53-93.

Hendrickx, S. (2008). Les grands mastabas de la Ire dynastie à Saqqara. Archéo-Nil 18: 60-88.

Hendrickx, S. (2011a). The chronology workshop. In Friedman, R. F., and Fiske, P. N. (eds.), Egypt at Its Origins 3, Peeters, Leuven, pp. 911-916.

Hendrickx, S. (2011b). Hunting and social complexity in Predynastic Egypt. Bulletin des Séances Mededelingen der Zittingen 57: 237-263.

Hendrickx, S., and Bavay, L. (2002). The relative chronological position of Egyptian Predynastic and Early Dynastic tombs with objects imported from the Near East and the nature of interregional contacts. In van den Brink, E. C., and Levy, T. (eds.), Egypt and the Levant: Interrelations from the 4th through the Early 3rd Millennium BCE, Leicester University Press, London, pp. 58-80.

Hendrickx, S., Darnell, J. C., and Gatto, M. C. (2012). The earliest representation of royal power in Egypt: The rock drawings of Nag el-Hamdulab (Aswan). Antiquity 86: 1068-1083.

Hendrickx, S., and Eyckerman, M. (2010). Continuity and change in the visual representation of Predynastic Egypt. In Raffaele, F., Nuzzolo, M., and Incordino, I. (eds.), Recent Discoveries and Latest Researches in Egyptology, Harrassowitz, Wiesbaden, pp. 121-144.

Hendrickx, S., and Eyckerman, M. (2012). Visual representation and state development. Archéo-Nil 22: 23-72.

Hendrickx, S., and Huyge, D. (2014). Neolithic and Predynastic Egypt. In Renfrew, C., and Bahn, P. (eds.), The Cambridge World Prehistory 1: Africa, South and Southeast Asia and the Pacific, Cambridge University Press, Cambridge, pp. 240-258.

Hendrickx, S., Midant-Reynes, B., and Van Neer, W. (2001). Mahgar Dendera 2 (Haute Egypte), un site d'occupation Badarien, Leuven University Press, Leuven.

Hendrickx, S., and van den Brink, E. C. (2002). Inventory of Predynastic and Early Dynastic cemetery and settlement sites in the Egyptian Nile Valley. In van den Brink, E. C., and Levy, T. (eds.), Egypt and the Levant: Interrelations from the 4th through the Early 3rd Millennium BCE, Leicester University Press, London, pp. 346-399.

Hikade, T. (2011). Origins of monumental architecture: Recent excavations at Hierakonpolis HK29B and HK25. In Friedman, R. F., and Fiske, P. N. (eds.), Egypt at Its Origins 3, Peeters, Leuven, pp. 81-107.

Hikade, T., Pyke, G., and O'Neill, D. (2008). Excavations at Hierakonpolis HK29B and HK25: The campaigns of 2005/2006. Mitteilungen des Deutschen Archäologischen Instituts Abteilung Kairo 64: 153-188.

Hill, J. (2004). Cylinder Seal Glyptic in Predynastic Egypt and Neighbouring Regions, BAR International Series 1223, Archaeopress, Oxford.

Hill, J., and Herbich, T. (2011). Life in the cemetery: Late Predynastic settlement at el-Amra. In Friedman, R. F., and Fiske, P. N. (eds.), Egypt at Its Origins 3, Peeters, Leuven, pp. 109-136.

Hoffman, M. A. (1979). Egypt Before the Pharaohs, Knopf, New York.

Hoffman, M. A. (1980). A rectangular Amratian house from Hierakonpolis and its significance for Predynastic research. Journal of Near Eastern Studies 39: 119-137.

Hoffman, M. A., Hamroush, H., and Allen, R. O. (1986). A model of urban development for the Hierakonpolis region from Predynastic through Old Kingdom times, Journal of the American Research Center in Egypt 23: 175-187.

Holdaway, S., Wendrich, W., and Phillipps, R. (2010). Identifying low-level food producers: Detecting mobility from lithics. Antiquity 84: 185-194.

Horn, M. (2014). A Badarian-Naqadian cognitive link? A possible insight on the basis of a Badarian hippopotamus-shaped pendant from Egypt. In Golani, A., and Wygńanska, Z. (eds.), Polish Archaeology in the Mediterranean 23/2, Special Studies: Beyond ornamentation: Jewelry as an Aspect of Material Culture in the Ancient Near East, University of Warsaw, Warsaw, pp. 41-70.

Inomata, T., and Coben, L. S. (eds.) (2006). Archaeology of Performance: Theatres of Power Community and Politics, AltaMira Press, Lanham, MD.

Jeffreys, D., and Tavares, A. (1994). The historic landscape of Early Dynastic Memphis. Mitteilungen des Deutchen Archaologischen Instituts, Abteilung Kairo 50: 143-173. 
Joffe, A. H. (2000). Egypt and Syro-Mesopotamia in the fourth millennium: implications of the new chronology. Current Anthropology 41: 113-123.

Jones, J., Higham, T. F., Oldfield, R., O'Connor, T. P., and Buckley, S. A. (2014). Evidence for prehistoric origins of Egyptian mummification in late Neolithic burials. Plos One 9: e103608 DOI:10.1371/journal.pone.0103608.

Jucha, M. (2010). Tell el-Murra: The Predynastic—Old Kingdom site in the North-East Nile Delta. Folia Orientalia 47: 379-390.

Jucha, M. (2011). Tell Abu el-Halyat: The new Naqada III—Old Kingdom (?) site in the north-eastern Nile Delta. Studies in Ancient Art and Civilization 15: 65-76.

Jucha, M. (2012). New Protodynastic serekhs from the Nile Delta: The case of finds from Tell el-Farkha. Polish Archaeology in the Mediterranean 21: 625-641.

Jucha, M., and Mączyńska, A. (2011). Settlement sites in the Nile Delta. Archéo-Nil 21: 33-50.

Junker, H. (1929). Vorläufiger Bericht über die Grabung der Akademie der Wissenschaften in Wien auf der neolithischen Siedlung von Merimde Benisalame (Westdelta). Anzeiger der Akademie der Wissenschaften in Wien, Philosophisch-historische Klasse 16: 156-250.

Kahl, J. (2001). Hieroglyphic writing during the fourth millennium BC: An analysis of systems. ArchéoNil 11: 103-125.

Kahl, J. (2006). Inscriptional evidence for the relative chronology of dyns. 0-2. In Hornung, E., Krauss, R., and Warburton, D. A. (eds.), Ancient Egyptian Chronology, Brill, Leiden, pp. 9-115.

Kaiser, W. (1957). Zur inneren Chronologie der Naqadakultur. Archaeologia Geographica 6: 69-77.

Kaiser, W., and Dreyer, G. (1982). Umm el-Qaab: Nachuntersuchungen im frühzeitlichen Königsfriedhof, 2. Vorbericht. Mitteilungen des Deutschen Archäologischen Instituts Abteilung Kairo 38: 211-269.

Kelly, R. L. (1992). Mobility/sedentism: Concepts, archaeological measures and effects. Annual Review of Anthropology 21: 43-66.

Kemp, B. (1968). Merimda and the theory of house burial in prehistoric Egypt: Chronique d'Égypte: Bulletin Périodique de la Fondation Égyptologique Reine Élisabeth 43: 22-23.

Kemp, B. (2006). Ancient Egypt: Anatomy of a Civilization, 2nd ed., Routledge, London.

Kobusiewicz, M., Kabaciński, J., Schild, R., Irish, J. D., and Wendorf, F. (2004). Discovery of the first Neolithic cemetery in Egypt's western desert. Antiquity 78: 566-578.

Kobusiewicz, M., Kabaciński, J., Schild, R., Irish, J. D., and Wendorf, F. (2009). Burial practices of the final Neolithic pastoralists at Gebel Ramlah, Western Desert of Egypt. British Museum Studies in Ancient Egypt and Sudan 13: 147-174.

Kobusiewicz, M, Kabaciński, J., Schild, R., Irish, J. D., Gatto, M. C., and Wendorf, F. (2010). Gebel Ramlah: Final Neolithic cemeteries from the Western Desert of Egypt, Institute of Archaeology and Ethnology, Polish Academy of Sciences, Poznań.

Köhler, C. (2004). On the origins of Memphis. In Hendrickx, S., Friedman, R. F., Ciałowicz, K. M., and Chłodnicki, M. (eds.), Egypt at Its Origins: Studies in Memory of Barbara Adams, Peeters, Leuven, pp. 295-315.

Köhler, C. (2008a). The interaction between the roles of Upper and Lower Egypt in the formation of the Egyptian state: Another review. In Midant-Reynes, B., and Tristant, Y. (eds.), Egypt at Its Origins 2, Peeters, Leuven, pp. 515-544.

Köhler, C. (2008b). The Helwan cemetery. Archéo-Nil 18: 113-130.

Köhler, C. (2010). Theories of state formation. In Wendrich, W. (ed.), Egyptian Archaeology, Blackwell, Oxford, pp. 36-54.

Köhler, C. (2011a). Introduction: La chronologie relative de la Basse Vallée du Nil jusqu'au 3e millénaire BC. Archéo-Nil 21: 5-11.

Köhler, C. (2011b). The rise of the Egyptian state. In Teeter, E. (ed.), Before the Pyramids: The Origins of Egyptian Civilization, Oriental Institute, University of Chicago, Chicago, pp. 127-130.

Köhler, C. (2014). Of pots and myths: Attempting a comparative study of funerary pottery assemblages in the Egyptian Nile Valley during the late 4th millennium BC. In Mączyńska, A. (ed.), The Nile Delta as a Centre of Cultural Interactions Between Upper Egypt and the Levant in the Fourth Millennium $B C$, Poznan Archaeological Museum, Poznań, pp. 155-180.

Köhler, C., and Birrell, M. (2005). Helwan I: Excavations in the Early Dynastic Cemetery Season 1997/98, Heidelberger Orientverlag, Heidelberg.

Köhler, C., Marshall, C., and El Karem, M. A. (2014). Helwan III: Excavations in Operation 4, Tombs 150, Marie Leidorf, Rahden/Westf. 
Kopp, P. (2007). Prä- und früdynastische Steingefässe: Chronologie und soziale Divergenz. Mitteilungen des Deutschen Archäologischen Instituts, Abteilung Kairo 63: 193-210.

Kroeper, K. (2004). Minshat Abu Omar: Aspects of the analysis of a cemetery. In Hendrickx, S., Friedman, R. F., Ciałowicz, K. M., and Chłodnicki, M. (eds.), Egypt at Its Origins: Studies in Memory of Barbara Adams, Peeters, Leuven, pp. 859-880.

Kroeper, K., and Wildung, D. (1994). Minshat Abu Omar: Ein vor- und frühgeschichtlicher Friedhof im Nildelta, Philipp von Zabern, Mainz am Rhein.

Kroeper, K., and Wildung, D. (2000). Minshat Abu Omar II: Ein vor- und frühgeschichtlicher Friedhof im Nildelta. Gräber 115-204, Philip von Zabern, Mainz am Rhein.

Lee, S., and Bronk Ramsey, C. (2012). Development and application of the trapezoidal model for archaeological chronologies. Radiocarbon 54: 107-122.

Lemonnier, P. (2012). Mundane Objects: Materiality and Non-Verbal Communication, Left Coast Press, Walnut Creek, CA.

Levine, A., and Stanish, C. (2014). The importance of multiple 14C dates from significant archaeological contexts. Journal of Archaeological Method and Theory 21: 824-836.

Linseele, V., Van Neer, W., and Friedman, R. F. (2009). Special animals from a special place? The fauna from HK29A at Predynastic Hierakonpolis. Journal of the American Research Center in Egypt 45: 105-136.

Linseele, V., Van Neer, W., Thys, S., Phillipps, R., Cappers, R., Wendrich, W., and Holdaway, S. (2014). New archaeozoological data from the Fayum "Neolithic" with a critical assessment of the evidence for early stock keeping in Egypt. PloSOne 9 DOI:10.1371/journal.pone.0108517.

Lohse, J. C. (2007). Commoner ritual, commoner ideology: (Sub-)alternate views of social complexity in prehispanic Mesoamerica. In Gonlin, N., and Lohse, J. C. (eds.), Commoner Ritual, Commoner Ideology in Ancient Mesoamerica, University Press of Colorado, Boulder, pp. 1-32.

Lohse, J. C., and Gonlin, N. (2007). Preface. In Gonlin, N., and Lohse, J. C. (eds.), Commoner Ritual, Commoner Ideology in Ancient Mesoamerica, University Press of Colorado, Boulder, pp. xvi-xlii.

Lull, V., and Micó, R. (2011). Archaeology of the Origin of the State, Oxford University Press, Oxford.

Mączyńska, A. (2011). The Lower-Egyptian-Naqada transition. In Friedman, R. F., and Fiske, P. N. (eds.), Egypt at Its Origins 3, Peeters, Leuven, pp. 879-908.

Mączyńska, A. (2013). Lower Egyptian Communities and their Interactions with Southern Levant in the 4th Millennium BC, Poznań Archaeological Museum, Poznań.

Mączyńska, A. (ed.) (2014a). The Nile Delta as a Centre of Cultural Interactions Between Upper Egypt and the Southern Levant in the 4th Millennium BC, Poznań Archaeological Museum, Poznań.

Mączyńska, A. (2014b). Some remarks on the visitors in the Nile Delta in the 4th Millennium BC. In Mączyńska, A. (ed.), The Nile Delta as a Centre of Cultural Interactions Between Upper Egypt and the Southern Levant in the 4th Millennium BC, Poznań Archaeological Museum, Poznań, pp. 181-205.

Mann, M. (1986). A History of Power from the Beginning to AD 1760: Volume 1 of The Sources of Social Power, Cambridge University Press, Cambridge.

Marcus, J. (2008). The archaeological evidence for social evolution. Annual Review of Anthropology 37: 251-266.

Marshall, F., and Hildebrand, E.A. (2002). Cattle before crops: The beginnings of food production in Africa. Journal of World Prehistory 16: 99-143.

Martin, G. T. (2011). Private Stelae of the Early Dynastic Period from the Royal Cemetery at Abydos, Harrassowitz, Wiesbaden.

Math, N. Ch. (2007). Eine innere Chronologie der Badarikultur? Möglichkeiten und Aspekte. Ägypten und Levante 17: 205-219.

Mawdsley, L. (2012). The foundation and development of Tarkhan during the Naqada IIIA2 period. In Evans, L. (ed.), Ancient Memphis: “Enduring Is the Perfection,” Leuven, Peeters, pp. 331-347.

McDonald, M. A. (2009). Increased sedentism in the central oases of the Egyptian Western Desert in the early to mid-Holocene: Evidence from the peripheries. African Archaeological Review 26: 3-43.

McGovern, P. E. (2001). The origins of the U-j Syro-Palestinian type jars as determined by neutron activation analysis. In Hartung, U. (ed.), Umm el-Qaab 2: Importkeramik aus dem Friedhof $U$ in Abydos (Umm el-Qaab) und die Beziehungen Ägyptens zu Vorderasien im 4, Jahrtausend v.Chr, Philipp von Zabern, Mainz am Rhein, pp. 407-416.

McGovern, P. E., Glusker, D. L., and Exner, L. J. (2001). The organic contents of the tomb U-j SyroPalestinian type jars: Resonated wine flavoured with fig. In Hartung, U. (ed.), Umm el-Qaab 2: 
Importkeramik aus dem Friedhof $U$ in Abydos (Umm el-Qaab) und die Beziehungen Ägyptens zu Vorderasien im 4: Jahrtausend v.Chr, Philipp von Zabern, Mainz am Rhein, pp. 399-403.

McGovern, P. E., Hartung, U., Badler, V. R., Glusker, D. L., and Exner, L. J. (1997). The beginnings of winemaking and viniculture in the ancient Near East and Egypt. Expedition 39: 3-21.

McGovern, P., Mirzoian, A., and Hall, G. R. (2009). Ancient Egyptian herbal wines. Proceedings of the National Academy of Sciences of the United States of America 106: 7361-7366.

McIntosh, S. K. (ed.) (1999). Beyond Chiefdoms: Pathways to Complexity in Africa, Cambridge University Press, Cambridge.

McNamara, L. (2008). The revetted mound at Hierakonpolis and early kingship. In Midant-Reynes, B., and Tristant, Y. (eds.), Egypt at Its Origins 2, Peeters, Leuven, pp. 901-936.

Midant-Reynes, B. (1987). Contribution à l'étude de la société prédynastique: le cas du couteau "rippleflake." Studien zur Altägyptischen Kultur 14: 185-224.

Midant-Reynes, B. (2000). The Prehistory of Egypt: From First Egyptians to the First Pharaohs (translated by I. Shaw), Blackwell, Oxford.

Midant-Reynes, B., Bruis, F., Bucez, N., De Dapper, M, Duschesne, S., Fabry, B., Hochstrasser-Petit, C., Staniaszek, L., and Tristant, Y. (2003). Kom el-Khilgan: Un nouveau site dans le Delta. Archéo-Nil 13: 55-64.

Midant-Reynes, B., Bruis, F., Buchez, N., De Dapper, M., Duschesne, S., Fabry, B., Hochstrasser-Petit, C., Staniaszek, L., and Tristant, Y. (2004). Kom el-Khilgan: A new site of the Predynastic period in Lower Egypt: the 2002 campaign. In Hendrickx, S., Friedman, R., Ciałowicz, K. M., and Chłodnicki, M. (eds.), Egypt at Its Origins: Studies in Memory of Barbara Adams, Peeters, Leuven, pp. 456-486.

Midant-Reynes, B., and Buchez, N. (2002). Adaïma. 1: Économie et habitat, Institut Francais d'Archeologie Orientale, Cairo.

Midant-Reynes, B., and Buchez, N. (2014). Tell el-Iswid. 2006-2009, Institut Francais d'Archeologie Orientale, Cairo.

Milner, G. R. (1998). The Archaeology of a Mississippian Society, Smithsonian Institution Press, Washington, DC.

Mitchell, T. (1991). The limits of the state: Beyond statist approaches and their critics. American Political Science Review 85: 77-96.

Molotch, H. (2011). Objects and the city. In Bridge, G., and Watson, S. (eds.), The New Blackwell Companion to the City, Wiley-Blackwell, Chichester, pp. 66-78.

Morris, E. F. (2007a). Sacrifice for the state: First Dynasty royal funerals and the rites at Macramallah's rectangle. In Laneri, N. (ed.), Performing Death: Social Analyses of Funerary Traditions in the Ancient Near East and Mediterranean, Oriental Institute, University of Chicago, Chicago, pp. 15-37.

Morris, E. F. (2007b). On the ownership of the Saqqara mastabas and the allotment of political and ideological power at the dawn of the state. In Hawass, Z. A., and Richards, J. (eds.), The Archaeology and Art of Ancient Egypt: Essays in Honor of David B. O'Connor, Vol. II, Supreme Council of Antiquities Press, Cairo, pp. 171-190.

Morris, E. F. (2014). (Un)dying loyalty: Meditations on retainer sacrifice in ancient Egypt and elsewhere. In Campbell, R. (ed.), Violence and Civilization: Studies of Social Violence in History, Oxbow Books, Oxford, pp. 61-93.

O'Connor, D. (2009). Abydos: Egypt's First Pharaohs and the Cult of Osiris, Thames and Hudson, London.

O'Connor, D., and Adams, M. D. (2003). The royal mortuary enclosures of Abydos and Hierakonpolis. In Hawass, Z. (ed.), Treasures of the Pyramids, American University in Cairo Press, Cairo, pp. 78-85.

Painter, J. (2006). Prosaic geographies of stateness. Political Geography 25: 752-774.

Patch, D. C. (1991). The Origin and Early Development of Urbanism in Ancient Egypt. A Regional Survey, Ph.D dissertation, Department of Near Eastern Languages and Civilizations, University of Pennsylvania, Philadelphia.

Patch, D. C. (2004). Settlement patterns and cultural change in the Predynastic period. In Hendrickx, S., Friedman, R. F., Ciałowicz, K. M., and Chłodnicki, M. (eds.), Egypt at Its Origins: Studies in Memory of Barbara Adams, Peeters, Leuven, pp. 905-918.

Pauketat, T. (2007). Chiefdoms and Other Archaeological Delusions, AltaMira Press, Lanham, MD.

Perry, P. (2011). Sources of power in Predynastic Hierakonpolis. In Friedman, R. F., and Fiske, P. N. (eds.), Egypt at Its Origins 3, Peeters, Leuven, pp. 1271-1292. 
Petrie, W. M. F. (1899). Sequences in prehistoric remains. Journal of the Royal Anthropological Institute of Great Britain and Ireland 3/4: 295-301.

Petrie, W. M. F. (1900). The Royal Tombs of the First Dynasty, Egypt Exploration Fund, London.

Petrie, W. M. F. (1901a). Diospolis Parva, Egypt Exploration Fund, London.

Petrie, W. M. F. (1901b). The Royal Tombs of the Earliest Dynasties, Egypt Exploration Fund, London.

Petrie, W. M. F. (1920). Prehistoric Egypt, British School of Archaeology in Egypt, London.

Petrie, W. M. F. (1925). Tombs of the Courtiers, British School of Archaeology in Egypt, London.

Petrie, W. M. F., and Quibell, J. E. (1896). Naqada and Ballas, Bernard Quaritch, London.

Phillipps, R., Holdaway, S., Wendrich, W., and Cappers, R. (2012). Mid-Holocene occupation of Egypt and global climatic change. Quaternary International 251: 64-76.

Pieri, A., and Antoine, D. (2012). Double delight: Another dwarf from HK5. Nekhen News 24: 7-8.

Porat, N., and Goren, Y. (2002). Petrography of the Naqada IIIa Canaanite pottery from Tomb U-j in Abydos. In van den Brink, E. C., and Levy, T. E. (eds.), Egypt and the Levant: Interrelations from the Fourth Through the Early Third Millennium BC, Leicester University Press, London, pp. 252-270.

Quibell, J. E., and Green, F. W. (1902). Hierakonpolis II, Bernard Quaritch, London.

Rappaport, R. A. (1999). Ritual and Religion in the Making of Humanity, Cambridge University Press, Cambridge.

Reinold, J. (2001). Kadruka and the Neolithic in the northern Dongola Reach. Sudan and Nubia 5: 2-10.

Rizkana, I., and Seeher, J. (1987). Maadi I: The Pottery of the Predynastic Settlement, Philipp von Zabern, Mainz am Rhein.

Rizkana, I., and Seeher, J. (1988). Maadi II: The Lithic Industries of the Predynastic Settlement, Philipp von Zabern, Mainz am Rhein.

Rizkana, I., and Seeher, J. (1989). Maadi III: The Non-Lithic Small Finds and the Structural Remains of the Predynastic Settlements, Philipp von Zabern, Mainz am Rhein.

Rizkana, I., and Seeher, J. (1990). Maadi IV: The Predynastic Cemeteries of Maadi and Wadi Digla, Philipp von Zabern, Mainz am Rhein.

Robb, J. (2008). The Early Mediterranean Village: Agency, Material Culture and Social Change in Neolithic Italy, Cambridge University Press, Cambridge.

Routledge, B. (2014). Archaeology and State Theory: Subjects and Objects of Power, Bloomsbury, London.

Rowland, J. M. (2009). Building bridges between radiocarbon, relative and historical chronologies: The case of early Egypt. In Vymazalová, H., and Bartá, M. (eds.), Chronology and Archaeology in Early Egypt (The Third Millennium BC), Czech Institute of Egyptology, Prague, pp. 37-43.

Rowland, J. M. (2013). Problems and possibilities for achieving absolute dates from early dynastic contexts. In Shortland, A. J., and Bronk Ramsey, C. (eds.), Radiocarbon and the Chronologies of Ancient Egypt, Oxbow, Oxford, pp. 235-249.

Rowland, J. M. (2014). Interregional exchange: The evidence from Kafr Hassan Dawood, East Delta. In Mączyńska, A. (ed.), The Nile Delta as a Centre of Cultural Interactions between Upper Egypt and the Southern Levant in the Fourth Millennium BC, Poznań Archaeological Museum, Poznań, pp. 269-298.

Rowland, J. M. (2015). Prehistoric groups along the western Nile Delta. Egyptian Archaeology 47: 37-39.

Rowland, J. M., and Tassie, G. (2014). Prehistoric sites along the edge of the western Nile Delta: Report on the results of the Imbaba prehistoric survey 2013-14. Journal of Egyptian Archaeology 100: 49-66.

Saad, Z. Y. (1969). The Excavations at Helwan: Art and Civilization in the First and Second Egyptian Dynasties, University of Oklahoma Press, Norman.

Sadig, A. M. (2010). The Neolithic of the Middle Nile Region: An Archaeology of Central Sudan and Nubia, Fountain, Kampala.

Salvatori, S., and Usai, D. (2008). A Neolithic Cemetery in the Northern Dongola Reach: Excavations at Site R12, Sudan Archaeological Research Society, London.

Savage, S. (1997). Descent group competition and economic strategies in Predynastic Egypt. Journal of Anthropological Archaeology 16: 226-268.

Savage, S. (2001a). Some recent trends in the archaeology of Predynastic Egypt. Journal of Archaeological Research 9: 101-155.

Savage, S. (2001b). Towards an AMS radiocarbon chronology of Predynastic Egyptian ceramics. Radiocarbon 43: 1255-1277. 
Schoenbrun, D. L. (1999). The (in)visible roots of Bunyoro-Kitara and Buganda in the Lakes region: AD 800-1300. In McIntosh, S. K. (ed.), Beyond Chiefdoms: Pathways to Complexity in Africa, Cambridge University Press, Cambridge, pp. 135-150.

Schortman, E. M. (2014). Networks of power in archaeology. Annual Review of Anthropology 43: $167-182$.

Schwartz, G. M. (2001). Syria and the Uruk expansion. In Rothman, M.S. (ed.), Uruk Mesopotamia and Its Neighbors: Cross-Cultural Interactions in the Era of State Formation, School of American Research Press, Santa Fe, NM, pp. 233-264.

Scott, J. C. (1998). Seeing Like a State: How Certain Schemes to Improve the Human Condition Have Failed, Yale University Press, New Haven, CT.

Serpico, M., and White, R. (2000). Resins, amber and bitumen. In Nicholson, P., and Shaw, I. (eds.), Ancient Egyptian Materials and Technology, Cambridge University Press, Cambridge, pp. 390-474.

Service, E. R. (1975). Origins of the State and Civilization: The Process of Cultural Evolution, Norton, New York.

Shirai, N. (2010). The Archaeology of the First Farmer-Herders in Egypt. New Insights into the Fayum Epipalaeolithic and Neolithic, Leiden University Press, Leiden.

Siedlmayer, S. J. (1996). Town and state in the early Old Kingdom. In Spencer, J. (ed.), Aspects of Early Egypt, British Museum Press, London, pp. 108-127.

Smith, A. T. (2011). Archaeologies of sovereignty. Annual Review of Anthropology 40: 415-432.

Spencer, P. (2011). Petrie and the discovery of earliest Egypt. In Teeter, E. (ed.), Before the Pyramids: The Origins of Egyptian Civilization, Oriental Institute, University of Chicago, Chicago, pp. 17-24.

Stein, G. J. (2001). Understanding ancient state societies in the Old World. In Feinman, G. M., and Price, T. D. (eds.), Archaeology at the Millennium, Kluwer Academic/Plenum Press, New York, pp. 353-379.

Stevenson, A. (2007). The material significance of Predynastic and Early Dynastic palettes. In Mairs, R., and Stevenson, A. (eds.), Current Research in Egyptology 2005: Proceedings of the Sixth Annual Symposium, Oxbow Books, Oxford, pp. 148-162.

Stevenson, A. (2008). Ethnicity and migration? The Predynastic cemetery of el-Gerzeh. In MidantReynes, B., Tristant, Y., Rowland, J., and Hendrickx, S. (eds.), Egypt at Its Origins 2, Peeters, Leuven, pp. 543-560.

Stevenson, A. (2009a). The Predynastic Egyptian Cemetery of el-Gerzeh, Peeters, Leuven.

Stevenson, A. (2009b). Predynastic burials. In Wendrich, W. (ed.), UCLA Encyclopaedia of Egyptology, Los Angeles (http://escholarship.org/uc/item/2m3463b2) (accessed 10/30/15).

Stevenson, A. (2009c). Social relationships in Predynastic burials. Journal of Egyptian Archaeology 95: $175-192$.

Stevenson, A. (2011). Material culture of the Predynastic period. In Teeter, E. (ed.), Before the Pyramids: The Origins of Egyptian Civilization, Oriental Institute, University of Chicago, Chicago, pp. 65-74.

Stevenson, A. (2012). Egypt and Mesopotamia. In Crawford, H. (ed.), The Sumerian World, Routledge, London, pp. 618-634.

Stevenson, A. (2015a). Telling times: Time and ritual in the formation of the Egyptian state. Cambridge Archaeological Journal 25: 145-161.

Stevenson, A. (2015b). Locating a sense of immortality in early Egyptian cemeteries. In Renfrew, C., Boyd, M., and Morley, I. (eds.), Death Rituals and Social Order in the Ancient World, Cambridge University Press, Cambridge, pp. 371-381.

Takamiya, I. H. (2004). Egyptian pottery distribution in A-Group cemeteries, Lower Nubia: Towards an understanding of exchange systems between the Naqada Culture and the A-Group Culture. Journal of Egyptian Archaeology 90: 35-62.

Takamiya, I. H. (2008). Firing installations and specialization: A view from recent excavations at Hierakonpolis Locality 11C. In Midant-Reynes, B., and Tristant, Y. (eds.), Egypt at Its Origins 2, Peeters, Leuven, pp. 187-202.

Terrenato, N., and Haggis, D. C. (eds.), (2011). State Formation in Italy and Greece: Questioning the Neoevolutionist Paradigm, Oxbow, Oxford.

Trigger, B. G. (1995). Ancient Egypt in Context, American University in Cairo Press, Cairo.

Tristant, Y. (2004). L'habitat prédynastique de la vallée du Nil: Vivre sur les rives du Nil aux $V^{e}$ et IV millénaires, BAR International Series 1287, Archaeopress, Oxford.

Tristant, Y. (2008a). Les tombes des premières dynasties à Abou Rawach. Bulletin de l'Institut Français d'Archéologie Orientale 108: 325-370. 
Tristant, Y. (2008b). Deux grand tombeaux du cimetièere M D’Abou Rawach (Ire dynastie). Archéo-Nil 18: $131-147$.

Tristant, Y., De Dapper, M., and Midant-Reynes, B. (2008). Human occupation of the Nile Delta during Pre- and Early Dynastic times: A view from Kom el-Khilgan. In Midant-Reynes, B., and Tristant, Y. (eds.), Egypt at Its Origins 2, Peeters, Leuven, pp. 463-482.

Tristant, Y., and De Dapper, M. (2009). Predynastic man and landscape in the Samara area (eastern Nile Delta, Egypt): A geo-archaeological approach. In De Dapper, M., and Vermeulen, F. (eds.), " $O l$ ' Man River": Geo-archaeological Aspects of Rivers and River Plains, Ghent University, Ghent, pp. 601-615.

Tristant, Y., and Midant-Reynes, B. (2011). The Predynastic cultures of the Nile Delta. In Teeter, E. (ed.), Before the Pyramids: The Origins of Egyptian Civilization, Oriental Institute, University of Chicago, Chicago, pp. 45-54.

Tristant, Y., and Smythe, J. (2011). New excavations for an old cemetery: Preliminary results of the Abu Rawash project on the M Cemetery (1st Dynasty). In Friedman, R. F., and Fiske, P. N. (eds.), Egypt at Its Origins 3, Peeters, Leuven, pp. 313-322.

van den Brink, E. C., and Levy, T. (eds.) (2002). Egypt and Levant: Interrelations from the Fourth Through the Early Third Millennium BCE, Leicester University Press, London.

Van Neer, W., and Du Cupere, B. (2014). For take away and delivery: Food preparation at HK11C. Nekhen News 26: 22-23.

von der Way, T. (1992). Excavations at Tell el-Fara'in/Buto in 1987-1989. In van den Brink, E. C. (ed.), The Nile Delta in Transition: 4th-3rd Millennium BC, Netherlands Institute of Archaeology and Arabic Studies in Cairo, Tel Aviv, pp. 1-10.

Watrall, E. C. (2001a). Excavations at locality HK 11. Nekhen News 12: 11-12.

Watrall, E. C. (2001b). Tales of trash. Nekhen News 13: 8-9.

Wendrich, W., and Cappers, R .T. (2005). Egypt's earliest granaries: Evidence from the Fayum. Egyptian Archaeology 27: 12-15.

Wengrow, D. (2001). Rethinking 'cattle cults' in early Egypt: Towards a prehistoric perspective on the Narmer Palette. Cambridge Archaeological Journal 11: 91-104.

Wengrow, D. (2003). Landscapes of knowledge, idioms of power: The African foundations of ancient Egyptian civilization reconsidered. In O'Connor, D., and Reid, A. (ed.), Ancient Egypt in Africa, Left Coast, Walnut Creek, CA, pp. 121-135.

Wengrow, D. (2006). The Archaeology of Early Egypt: Social Transformations in North-east Africa, 10,000 to 2650 BC, Cambridge University Press, Cambridge.

Wengrow, D. (2009). Limits of decipherment: Object biographies and the invention of writing. In MidantReynes, B., and Tristant, Y. (eds.), Egypt at Its Origins 2, Peeters, Leuven, pp. 1021-1032.

Wengrow, D. (2010). What Makes Civilization? Oxford University Press, Oxford.

Wengrow, D. (2011). The invention of writing in Egypt. In Teeter, E. (ed.), Before the Pyramids: The Origins of Egyptian Civilization, Oriental Institute, University of Chicago, Chicago, pp. 103-107.

Wengrow, D. (2013). The Origins of Monsters. Image and Cognition in the First Age of Mechanical Reproduction, Princeton University Press, Princeton, NJ.

Wengrow, D., Dee, M., Foster, S., Stevenson, A., and Bronk Ramsey, C. (2014). Cultural convergence in the Nile valley Neolithic: A prehistoric perspective on Egypt's place in Africa. Antiquity 88: 95-111.

Wengrow. D., and Graeber, D. (2015). Farewell to the 'childhood of man': Ritual, seasonality and the origins of inequality. Journal of the Royal Anthropological Institute 21: 597-619.

Wenke, R. (2009). The Ancient Egyptian State: The Origins of Egyptian Culture (c.8000-2000 BC), Cambridge University Press, Cambridge.

Whittle, A. (2005). Lived experience in the Neolithic of the Great Hungarian Plain. In Bailey, D., Whittle, A., and Cummings, V. (eds.), Un-settling the Neolithic, Oxbow, Oxford, pp. 64-70.

Wilkinson, R. (2000). The Complete Temples of Ancient Egypt, Thames and Hudson, London.

Wilkinson, T. (1999). Early Dynastic Egypt, Routledge, London.

Wilkinson, T. (2000). Political unification: Towards a reconstruction. Mitteilungen des Deutschen Archäologischen Instituts, Abteilung Kairo 56: 377-395.

Williams, B. (1986). The A-Group Royal Cemetery at Qustul, Cemetery L, Oriental Institute, University of Chicago, Chicago.

Wilson, P. (2006). Prehistoric settlement in the Western Delta: A regional and local view from Sais (Sa El-Hagar). Journal of Egyptian Archaeology 92: 75-126.

Wilson, P. (2014). Sais II: The Prehistoric Period at Sa el-Hagar, Egypt Exploration Society, London. 
Wright, H. T. (2006). Early state dynamics as political experiment. Journal of Anthropological Research 62: $305-319$.

Wright, H. T., and Rupley, E. S. (2001). Calibrated radiocarbon age determinations of Uruk-related assemblages. In Rothman, M. S. (ed.), Uruk Mesopotamia and its Neighbors: Cross-Cultural Interactions in the Era of State Formation, School of American Research Press, Santa Fe, NM, pp. $85-122$.

Yaeger, J., and Canuto, M. A. (eds.) (2000). The Archaeology of Communities: A New World Perspective, Routledge, London.

Yoffee, N. (2001). The evolution of simplicity: Review of James C. Scott, Seeing like a State. Current Anthropology 42: 767-769.

Yoffee, N. (2005). Myths of the Archaic State: Evolution of the Earliest Cities, States, and Civilizations, Cambridge University Press, New York.

\section{Bibliography of Recent Literature}

Anfinset, N. (2010). Metals, Nomads and Culture Contact: The Middle East and North Africa, London, Equinox.

Angevin, R. (2015). The hidden Egyptian workshop: The lithic grave goods of King Khasekhemwy. Antiquity 89: 818-837.

Bestock, L. (2007). Finding the First Dynasty royal family. In Hawass, Z. A., and Richards, J. (eds.), The Archaeology and Art of Ancient Egypt: Essays in Honor of David B. O'Connor I, Supreme Council of Antiquities Press, Cairo, pp. 99-108.

Hendrickx S (1995) Analytical Bibliography of the Prehistory and the Early Dynastic Period of Egypt and the Northern Sudan has been continually updated and published annually in Archéo-Nil since its sixth volume in 1996. It now runs to some 15,000 titles, thousands of which also can be found in the Online Egyptological Bibliography (OEB). Since 2002 an international conference, Egypt at Its Origins, has been held every three to four years, the conference proceedings from which bring together many recent finds from the field. In addition to what is cited above, this bibliography represents a select number of the more substantial publications from 2001 onwards on the subject of Predynastic Egypt.

Hendrickx, S. (2014). The emergence of the Egyptian state. In Renfrew, C., and Bahn, P. (eds.), The Cambridge World Prehistory, Cambridge University Press, Cambridge, pp. 259-278.

Hendrickx, S., and Huyge, D. (2014). Neolithic and Predynastic Egypt. In Renfrew, C., and Bahn, P. (eds.), The Cambridge World Prehistory, Cambridge University Press, Cambridge, pp. 240-258.

Hendrickx, S., Huyge, D., and Wendrich, W. (2010). Worship before writing. In Wendrich, W. (ed.), Egyptian Archaeology, Blackwell, Oxford, pp. 15-35.

Hendrickx, S., and Vermeersch, P. (2000). Prehistory: From the Palaeolithic to the Badarian culture. In Shaw, I. (ed.), The Oxford History of Ancient Egypt, Oxford University Press, Oxford, pp. 17-44.

Jucha, M., Dębowska-Ludwin, J., and Kołodziejczyk, P. (eds.) (2014). Aegyptus est imago caeli: Studies presented to Krzysztof M. Ciatowicz on his 60th birthday, Institute of Archaeology, Jagiellonian University in Krakow, Krakow.

Kabaciński, J., Chłodnicki, M., and Kobusiewicz, M. (eds.) (2012). Prehistory of Northeastern Africa: New Ideas and Discoveries, Poznań Archaeological Museum, Poznań.

Kopp, P. (2006). Elephantine XXXII: Die Siedlung der Naqadazeit, Philipp von Zabern, Mainz am Rhein.

Krzyżaniak, L., Kroeper, K., and Kobusiewicz, M. (eds.) (2003). Cultural Markers in the Later Prehistory of Northeastern Africa and Recent Research, Poznań Archaeological Museum, Poznań.

Lankester, F. (2013). Desert Boats: Predynastic and Pharaonic Era Rock-Art in Egypt's Central Eastern Desert, Archaeopress, Oxford.

Mączyńska, A. (2015). Lower and Upper Egypt in the 4th millennium BC: The development of craft specialisation and social organisation of the Lower Egyptian and Naqada cultures. In Kabaciński, J., Chłodnicki, M., and Kobusiewicz, M. (eds.), Hunter-Gatherers and Early Food Producing Societies in Northeastern Africa. Poznań Archaeological Museum, Poznań, pp. 65-101.

Midant-Reynes, B. (2003). Aux origins de l'Égypte: Du Néolithique à l'emergence de l'État, Fayard, Paris.

Patch, D. (2012). Dawn of Egyptian Art, Metropolitan Museum of Art, New York.

Regulski I. (2010). A Palaeographic Study of Early Writing in Egypt, Peeters, Leuven. 
Rowland, J. M. (2007). Death and the origins of Egypt: Mortuary variability as an indicator of sociopolitical change during the Late Predynastic to Early Dynastic period. In Goyon, J.C., and Cardin, C. (eds.), Proceedings of the Ninth International Congress of Egyptologists, Grenoble, 6-12 September 2004, Peeters, Leuven, pp. 1629-1643.

Tassie, G. J. (2014). Prehistoric Egypt: Socioeconomic Transformations in Northeast Africa from the Last Glacial Maximum to the Neolithic, 24,000 to 6,000 cal. BP, Golden House, London.

Wengrow, D. (2009). Predynastic art. In Wendrich, W. (ed.), UCLA Online Encyclopaedia of Egyptology, Los Angeles (http://escholarship.org/uc/item/5gk265x0). 